\title{
Ideološki pogledi Milana Šufflaya
}

\author{
TOMISLAV KARDUM \\ Zagreb, Hrvatska \\ tkardum96@gmail.com
}

Rad nastoji uklopiti ideološke poglede Milana Šufflaya u širi europski kontekst antimodernističkih i antiprosvjetiteljskih tendencija. S time je povezan i Šufflayev pogled na hrvatsku naciju i hrvatski nacionalni identitet. U radu se razmatraju i Šufflayeva geopolitička promišljanja. Šufflay je kritičar modernoga svijeta i njegovih manifestacija, zastupnik je organskoga nacionalizma, a hrvatski nacionalni identitet konstruira nasuprot jugoslavenskom, ističući važnost povijesnoga pamćenja, kulture, geografije i rase pri oblikovanju nacije, a marginalizirajući značenje jezika. Isticat će katoličku vjersku pripadnost Hrvata i pripadnost zapadnoj civilizaciji kao temeljne značajke hrvatskoga nacionalnog identiteta.

Ključne riječi: Milan Šufflay; antimodernizam; organski nacionalizam; hrvatski nacionalizam; geopolitika

\section{Uvod}

Milan Šufflay (1879. - 1931.) zbog svojega raznovrsnog, ali minucioznog znanstvenog rada jedan je od najpoznatijih hrvatskih intelektualaca prve polovine XX. stoljeća. Prema Ivi Bancu, Šufflay je zbog znatnoga intelektualnog doprinosa svojega stvaralaštva „najistaknutiji” od nepoznatih „velikih javnih osoba” u Hrvatskoj XX. stoljeća. ${ }^{1}$ Ipak, dosadašnji proučavatelji lika i djela Milana Šufflaya malo su pozornosti posvećivali njegovoj publicističkoj djelatnosti i predodžbama koje je preko nje nastojao prenijeti širem krugu čitatelja raznih novina i časopisa 1920-ih (Hrvatsko pravo, Novosti, Jutarnji list, Hrvatska misao, Starohrvatska prosvjeta, Obzor, Pantheon, Književnik i Hrvatska revija).

\footnotetext{
BANAC, „Zarathustra in Red Croatia”, 181.
} 
Šufflay djeluje u vrijeme kad je u intelektualnim krugovima bila izrazito raširena sumnja u tekovine prosvjetiteljstva te se izgubila „vjera u napredak” karakteristična za veći dio XIX. stoljeća. Pesimizam je zamijenio optimizam prethodnoga stoljeća. Šufflayevo se djelovanje i ideološki pogledi ne mogu razumjeti ako se promatraju u vakuumu. Oni se moraju promatrati uzimajući u obzir „duh vremena” i intelektualne tendencije koje su se tada proširile i u Hrvatskoj. U ovom su radu Šufflayevi tekstovi u tisku i publicistička djelatnost podijeljeni u tri kategorije: kritika modernosti, Šufflayev pogled na naciju te njegova geopolitička razmišljanja. Podjela na te tri cjeline prirodno se nameće iz Šufflayevih radova, a sve ih objedinjuje njegova antiprosvjetiteljska pozicija povezana s intelektualnim strujanjima i „duhom vremena”.

U tom kontekstu razni autori koji su se dosad bavili njegovim likom i djelom nisu odgovarajuće i sveobuhvatno, nego paušalno u pojedinim radovima, obradili Šufflayevo stvaralaštvo i ideologiju. ${ }^{2}$ Šufflayevo stvaralaštvo rijetki su uklopili u širi europski kontekst rasta antimodernističkih, antiprosvjetiteljskih nastojanja. Ivo Banac reći će u članku usredotočenom na Šufflayeva razmišljanja o hrvatskoj naciji da Šufflaya, kao pristašu „starije nacionalističke ideologije”, treba razlikovati od nove hrvatske međuratne desnice. Upravo suprotno, Šufflay je pripadnik novoga naraštaja hrvatskih nacionalista i zastupnik organskoga koncepta nacije te stoji u opreci spram „starih” nacionalista. ${ }^{3}$ Maša Grdešić i Zoran Kravar jedini su nagovijestili, u neznanstvenim časopisima, na koji način treba proučavati Šufflayeve ideološke poglede, odnosno da ga treba proučavati kao predstavnika antimodernističkoga duha vremena. Kravar je sugerirao da je Šufflayeva ideologija slična ideologijama europske desnice u međuratnom razdoblju te u tom kontekstu navodi Juliusa Evolu, Georgesa Sorela, konzervativne revolucionare Arthura Moellera van den Brucka, Edgara Junga i Oswalda Spenglera. ${ }^{4}$ Ipak, Kravarov je članak opsegom dvije stranice te je samo putokaz, a tema nije elaborirana, i jedino je Grdešić malo dublje zašla u temu, iz antimodernističkoga kuta gledanja, ali nije analizirala Šufflayev

\footnotetext{
2 Josip Horvat daje pregled Šufflayeva djelovanja i njegovu romansiranu biografiju. Josip Matota u prvom dijelu knjige analizirao je Šufflayevo shvaćanje uloge povijesti u narodnoj svijesti, a u drugom dijelu obrađuje sukob Ferde Šišića i Šufflaya. Biografska knjiga Darka Sagraka o Milanu Šufflayu publicističke je naravi te ideologizirana. Hrvoje Matković analizirao je u članku Šufflayev pokušaj stvaranja Hrvatske radikalne stranke, ali nije posebno obrađivao pitanje Šufflayevih ideoloških pogleda. Dubravko Jelčić u predgovoru Izabranih političkih spisa Milana Šufflaya donosi neke korisne tvrdnje o Šufflayevim ideološkim pogledima, koje nije eksplicirao, ali su objašnjene u ovom radu. Naime, Jelčić upozorava na srodnost Šufflayeva „četvrtoga doba” i Berdjajevljeva Novoga srednjovjekovlja te pokazuje da su neka Šufflayeva gledišta bliska Huntingtonovoj tezi o sukobu civilizacija. HORVAT, Hrvatski panoptikum, 171-228; MATOTA, Šuflayevo shvaćanje uloge povijesti; SAGRAK, Dr. Milan pl. Šufflay; MATKOVIĆ, „Šufflayeva akcija za osnivanje Hrvatske narodne radikalne stranke”, 167-173; JELČIĆ, „Predgovor”, 19-25.

BANAC, „Zarathustra in Red Croatia”, 193.

4 KRAVAR, „Revizionizam tvrdo ukoričen”, 15; GRDEŠIĆ, „Oni nas vode na Balkan”, 18-27.
} 
odnos prema hrvatskome nacionalizmu i način na koji Šufflay konstruira hrvatski nacionalni identitet, kao ni njegova geopolitička razmišljanja.

Milan Šufflay i kritika „modernoga” svijeta

U posljednjem desetljeću XIX. stoljeća počinje odbacivanje liberalizma, materijalizma, univerzalizma, vjere u napredak i razum, pozitivizma i sl. Razum, koji je bio na pijedestalu, sve više zamjenjuju subjektivizam, vitalizam i antiuniverzalizam, a nasuprot individualizmu glorificiraju se kolektivizam i organski poredak. Povjesničar Stanley G. Payne taj proces naziva „kulturalnom transformacijom fin de sièclea”. Jedan od predvodnika nove struje, Friedrich Nietzsche, pozvao je na "prevrednovanje svih vrijednosti”. "Stare” ideje prosvjetiteljstva i modernosti nisu odbačene, ali usporedno s njima teče spomenuti proces. Zato Zeev Sternhell govori o dvije modernosti, koje su jedna drugoj suprotstavljene. Prva je modernost prosvjetiteljska, a druga antiprosvjetiteljska. Sternhell prati antiprosvjetiteljsku tradiciju od Giambattiste Vica preko Johanna Gottfrieda Herdera pa do antiprosvjetiteljskih intelektualaca kraja XIX. stoljeća i međuraća. ${ }^{7}$ Potonji, u koje spadaju Charles Maurras, George Sorel, Maurice Barrès, Henri Bergson, Oswald Spengler, Friedrich Nietzsche i drugi, važni su za razumijevanje ideoloških pogleda Milana Šufflaya. Oni će kritizirati vjeru u napredak, pozitivizam, modernu civilizaciju, materijalizam i gubitak/marginaliziranje spiritualnih vrijednosti te će većinom prihvatiti socijaldarvinizam. ${ }^{8} \mathrm{U}$ međuratnom se razdoblju, riječima Tomislava Sunića, događa „konzervativna intelektualna revolucija” koju se naziva i „organskom revolucijom”. Intelektualci koji su sudjelovali u konzervativnoj revoluciji bili su protuliberalni jer napadaju liberalni koncept pojedinca i „mehanički” koncept društva, zagovarajući iskonsko, organsko društvo u kojem je kolektivitet iznad pojedinca. Također su bili izrazito protusocijalistički usmjereni. ${ }^{9}$

Šufflay se ne poziva na sve spomenute autore, ali su neke od njegovih ideja bliske tim autorima i antiprosvjetiteljskoj tradiciji. On će u svojim tekstovima iz antimoderne, antiprosvjetiteljske pozicije kritizirati moderni svijet, pozitivizam, industrijalizaciju, individualizam i gradsku civilizaciju te zagovarati

PAYNE, A History of Fascism, 23-34.

Isto, 25.

STERNHELL, The Anti-Enlightenment Tradition. Kravar pak govori o antimodernizmu „osobito protumodernom raspoloženju tipičnom za kasnograđansku epohu”, koje odvaja od romantičkoga i postmodernoga kriticizma. Ta je podjela vrlo slična gore spomenutoj, samo što koristi dihotomiju moderno - antimoderno umjesto prosvjetiteljstvo - antiprosvjetiteljstvo. KRAVAR, Antimodernizam, 17.

8 STERNHELL, The Anti-Enlightenment Tradition, 315-372.

9 SUNIĆ, Europska nova desnica, 85-86. 
povratak srednjovjekovlju i „iskonu”, kao i vitalizam. U prvom je redu to vidljivo u njegovim objavljenim recenzijama radova stranih intelektualaca koji su pisali o ovim temama te u drugim Šufflayevim člancima objavljivanim u raznim novinama i časopisima. „Znanost učinila je ljude bez dvojbe jačima. Zašto ih nije učinila sretnijima?! Devetnaesto stoljeće, taj raj znanstvenih luđaka, tvrdilo je da će to uslijediti. I ovo XIX. stoljeće svršilo se 1. kolovozom 1914.”, napisat će Šufflay kritizirajući vjeru u progres i scijentizam. ${ }^{10}$ Znanost je, smatra on, povećala „ljudsku kontrolu nad prirodom”, ali nije povećala blagostanje čovječanstva. To bi nastupilo da su ljudi „racijonalna bića. Nu uistinu oni su puni strasti i pranagona" ${ }^{11}$ Šufflay u (pre)brzom znanstvenom napretku vidi veliku opasnost jer iracionalna ljudska bića nisu etički osvijestila što znanstveni napredak znači i što sve može proizvesti. Znanstveni napredak bez usporednoga etičkog napretka uzrokovao je i omogućio veliku sofisticiranu klaonicu Prvoga svjetskog rata. Šufflay zaključuje da je potrebna „ravnoteža između znanstvene spreme ljudi i njihove umne i moralne spreme. Ali tehnički progres neprispodobivo je brži od etičkog progresa. I zato nema nade". ${ }^{12}$ Šufflay je smatrao da su čovjeka porobili strojevi - „demonskim svojim progresom od bijelca učiniše svog roba". ${ }^{13}$

Oswald Spengler u svojoj utjecajnoj knjizi Propast Zapada (Der Untergang des Abendlandes) iznosi vlastitu viziju cikličke povijesti. Spengler uspostavlja analogiju između kulture i organizma. Prema njegovu mišljenju, svaka kultura, a tijekom povijesti ih je identificirao osam, ima periode razvoja, vrhunca i neizbježnoga propadanja ili, kako ih Spengler označuje: proljeće, ljeto, jesen i zimu. Svaka od osam kultura njeguje distinktivni „duh” s posebnim karakteristikama koje se očituju u kulturi. Dakle, ne postoji „čovječanstvo”, koje je za Spenglera „zoološki koncept ili prazna fraza”, i univerzalna povijest. „Duh” zapadne civilizacije je „faustovski”. Faustovska je civilizacija, zaključuje Spengler, ušla u „zimu”, odnosno nazadovanje (kultura se pretvorila u civilizaciju), nakon čega će uslijediti i propast. Europa je ušla u zimu nakon industrijske revolucije, kada se ruše stari, tradicionalni oblici života, a umjesto nje dolazi li-

\footnotetext{
10 ŠUFFLAY, „Tehnika i etika: Bertrand Russell”, Hrvatsko pravo (Zagreb), 6. 9. 1924., u: JELČIĆ, Milan Šufflay. Izabrani politički spisi (dalje: IPS), 162. Šufflay vjerojatno uzima 1. kolovoza 1914. kao važnu prekretnicu jer toga dana Njemačka objavljuje rat carskoj Rusiji, čime Prvi svjetski rat dobiva mnogo šire razmjere.

11 Isto.

12 Isto. Šufflay ne koristi taj termin, ali opisuje pojavu koju je sociolog William F. Ogburn nazvao cultural lag. Prema tom konceptu, kultura se mora prilagoditi tehnološkom razvoju budući da su prvotno u diskrepanciji. OGBURN, „Cultural Lag as Theory”, 167-174.

13 ŠUFFLAY, „Val ratne krivnje”, Hrvatska revija (Zagreb), 1929., u: IPS, 249. I drugi antimodernisti tako gledaju na napredak koji donosi otuđenje, primjerice Ludwig Klages, Alfred Schuler, Julius Evola knjigom Pobuna protiv modernog svijeta. GRDEŠIĆ, „Oni nas vode na Balkan”, 23.
} 
beralno-demokratska ideologija. ${ }^{14}$ Spenglerova je knjiga bila izrazito utjecajna, a Šufflay će ju prikazati 1929. godine. On se slaže s temeljnom Spenglerovom postavkom te ga naziva „žrecom zapada”. Smatra da Spengler ima pravo što se tiče dekadencije zapadne civilizacije. ${ }^{15}$ Nijedna europska država, osim Velike Britanije, prema Šufflayu, nije „država prvog reda”, a politika europskih država prema Sovjetskom Savezu gurnula ga je Aziji. Šufflay predviđa da će uskoro azijska hegemonija zamijeniti američku. Zato se cijeli Zapad treba okupiti oko anglo-američkoga bloka, koji je „jezgra spasa”. ${ }^{16}$ Moguće je da Šufflay hrvatsku javnost upoznaje sa Spenglerovim idejama, ili samo želi utjecati na članove Hrvatske stranke prava (HSP) s obzirom na to je tekst objavljen u stranačkom glasilu. Svakako je simptomatično referiranje na Spenglera u stranačkom glasilu, što bi mogao biti važan element u proučavanju ideoloških gibanja unutar HSP-a 1920-ih. ${ }^{17}$

Šufflay ne ostaje samo na kritici industrijaliziranoga Zapada. Kako ističe Kravar, antimodernisti se zalažu za svijet koji je suprotstavljen moderni. To su većinom navodni, idilični „protusvjetovi” koji su postojali prije moderne. ${ }^{18} \mathrm{Ri}$ ječ je, kaže Kravar, o svojevrsnom mitu o zlatnom dobu koje je nekoć navodno postojalo, a koje je, prema antiprosvjetiteljskoj tradiciji, izgubljeno kad je moderni svijet atomizirao čovjeka i razrušio srednjovjekovni organski poredak. Tada je nastao materijalistički antiduhovni pojedinac. ${ }^{19}$ Šufflay rješenje vidi u novom, „četvrtom dobu” - „novom srednjovjekovlju”. Sintagma je to koju koristi poznati filozof Nikolaj A. Berdjajev u istoimenoj knjizi Novo srednjovjekovlje iz 1924. godine. Berdjajev iznosi ideje koje imaju zapanjujuću sličnost sa Šufflayevima. On smatra da se događa dehumanizacija čovjeka, koji postaje „slika i prilika stroja”. Slično kao i Šufflay, smatra da je čovjekom zavladao stroj. Čovjek je postao „oruđe proizvodnje”, drži Berdjajev. ${ }^{20}$ Berdjajev, kao i Šufflay, nije eo ipso protiv nove tehnologije, nego smatra da ljudska svijest nije

\footnotetext{
14 SUNIĆ, Europska nova desnica, 98-103.

15 ŠUFFLAY, „Žreci istoka i zapada”, Hrvatsko pravo, 29. 6. 1929., u: IPS, 160.

$16 \quad$ Isto, 161.

17 O HSP-u u Kraljevini Srba, Hrvata i Slovenaca vidi: JAREB, Ustaško-domobranski pokret, 33-67. Važno je istaknuti da Milan Šufflay u Austro-Ugarskoj nije bio pravaš, nego je bio povezan s unionistima. Bio je prijatelj bana Pavla Raucha, a namještenje u Budimpešti osigurao mu je poznati mađarski povjesničar Ljudevit Thallóczy. Kao povjesničar se za vrijeme Austro-Ugarske sukobio s hrvatskim „nacionalnim” povjesničarima jer je u polemici s Nikolom Tomašićem ustvrdio da je Pacta conventa falsifikat. HORVAT, Hrvatski panoptikum, 178-189.

18 KRAVAR, Antimodernizam, 56.

19 STERNHELL, The Anti-Enlightenment Tradition, 8.

20 SELAK, „Bioetički osvrt na filozofiju Nikolaja A. Berdjajeva”, 607-608. Berdjajev u Novom srednjovjekovlju iznosi i druge ideje slične Šufflayevima, pa tako oštro kritizira ,individualističku civilizaciju XIX. vijeka s njenom demokracijom, s njenim materijalizmom, s njenom tehnikom, s javnim mnijenjem, štampom, burzom i parlamentom”. Ta je „bezbožna i licemjerna civilizacija”, pisao je Berdjajev, „porodila svjetski rat”. BERDJAJEV, Novo srednjovjekovje, 17, 103.
} 
dovoljno razvijena da bi njome upravljala. U „novom srednjovjekovlju” čovjek će postati duhovan i shvatiti tehniku kao duhovno pitanje. Berdjajevljevo je novo doba obilježeno etičnošću i religioznošću ljudi. ${ }^{21}$

Šufflay korijen modernih problema vidi u uništavanju sela i brzoj industrijalizaciji. Koristeći znanstveni diskurs i pozivajući se na prirodoslovne znanstvenike, on opravdava svoju teoriju. Reći će da se život na zemlji može podijeliti na ono što njemački filozof i kemičar Wilhelm Ostwald naziva anabiontima i katabiontima. Izvorni, važniji sloj je tzv. anabiont ili, Šufflayevim riječima, bilina. Životinje (katabionti) „parazitiraju” na bilini. Stoga je „tako dugo, dok ljudski mozak ne otkrije tajnu biline, klorofilnu funkciju njenog zelenog lista, jedina istinski vitalna industrija kult biline, obrađivanje polja". ${ }^{22}$ Industrijalizacija i urbanizacija uništavaju selo, a upravo je selo „posrednik između biline i varoškog pučanstva”. Tako se stvaraju „robovi mašina koji otkinuti od spoja s majčicom zemljom [kurziv dodao T. K.], predstavljaju čardak ni na Nebu ni na Zemlji”, a potvrđuje se „da je jedino prava i zdrava industrija baš obrađivanje polja”. ${ }^{23}$ Ipak, Šufflay je svjestan da se kotač povijesti ne može zaustaviti, zbog čega je potrebno poduzeti mjere za zaštitu sela i seljaka. Seljački su narodi u prednosti jer mogu „regulirati bujanje industrije i urbanizacije”, što je njihova „životna snaga”. Šufflay, kao i Spengler, prezire gradsku civilizaciju i kozmopolitizam, a korištena fraza o „organskom spoju s majčicom zemljom” govori o upućenosti u diskurs Spengleru sličnih intelektualaca koji su glorificirali selo i srednjovjekovnu organsku povezanost čovjeka sa zemljom. Za Šufflaya su veliki gradovi „prazne posude izdahle duše, u koje se lagano gnijezdi čovječanstvo bez historije”, odnosno stanovništvo bez „korijena” i povezanosti sa zemljom, svojom kulturom, poviješću i civilizacijom. ${ }^{24}$ Na Šufflayevu sumnju prema obilježjima (urbanizacija, industrijalizacija itd.) svijeta koji je u XIX. stoljeću stvorilo građanstvo, odnosno na njegov konzervativizam i antimodernizam, možda je utjecalo i socijalno podrijetlo. Naime, rođen je u obitelji sitnoga plemstva. Njegov predak Matija Šufflay dobio je 1675. od cara Leopolda I. plemićki status, a obitelj je bila poznata kao Šufflay od Otruševca. ${ }^{25}$

\footnotetext{
${ }^{21}$ SELAK, „Bioetički osvrt na filozofiju Nikolaja A. Berdjajeva”, 609-613. Slično je promišljao povjesničar Johan Huizinga. I on je rješenje modernih problema vidio u povratku duhovnosti i većoj ulozi kršćanstva, koje bi bilo most između kolektivizma i individualizma. HUIZINGA, $U$ sjeni sutrašnjice.

22 ŠUFFLAY, „Bezvremeno selo: Urbanizacija i civilizacija”, Hrvatsko pravo, 6. 7. 1929., u: IPS, 262 .

23 Isto.

24 ŠUFFLAY, „Suton zapadne civilizacije, Spengler i Russell, Bergson i Semon”, Pantheon (Zagreb) I (1929), br. 3, u: IPS, 290.

25 HORVAT, Hrvatski panoptikum, 174. Konzervativizam, kao ideologija plemstva, oblikuje se u relaciji spram Francuske revolucije i liberalizma (ideologija građanstva). No to ne znači, kako
} 
Antimodernistička dihotomija organsko - mehaničko i samoniklo - načinjeno predstavljena je u Šufflayevu rezoniranju, kao i u Spenglerovu. ${ }^{26} \mathrm{Grad}$ je tako obilježje umjetne, mehaničke, neorganske civilizacije, nasuprot organskom selu, koje se uništava. Zato je rješenje nedaća u povratku svijetu koji je predstavljao organsko. Rješenje je „novo srednjovjekovlje”, odnosno povratak srednjovjekovnim vrijednostima (čast, viteštvo, duhovnost itd.) i organskom poretku. Šufflay smatra da Prvi svjetski rat obilježava početak „goleme mutacije"27, odnosno početak sloma materijalističkoga svjetonazora. Njegov opis „novoga doba” u članku iz 1929. sličan je Berdjajevljevu:

„Stojimo na pragu novog, s historijskog gledišta četvrtog doba, pred novim i golemim izdanjem prošlog 'srednjeg vijeka', u koje će i opet jedamput etičkim vrednotama biti posvećena veća pažnja, u kojem će ljudima i opet svijetliti svjetlo drugog svijeta, kako je ono počelo svijetliti na koncu starog Rimskog Carstva. Za ovo svjetlo bornirani moderni materijalizam nije imao ćutila, pak je čitavoj velikoj periodi evropske povijesti, kojom je pokretala religija i Crkva, dao ime 'vijek tame'!28 U religiji je sadržana svemirska tajna, refleks čitavog jednog kosmosa, koji nije materijalan i ćutilima pristupačan, teleološki faktor, usađen u besmrtnu klicu Života [kurziv dodao T. K.], a ne u jednodnevni mozak životnih postaja. U religiji leži najveće znanje uzdužnog i poprečnog reza ljudskog roda i bitni uvjet za pravu sreću svakog pojedinca." ${ }^{29}$

Novo doba, koje će nastupiti nakon spenglerovske propasti Zapada, „poput divne mahovine pokrit će bogobojazni seljački sloj, tražitelj Boga, graditelj doma i općine, promicatelj ritmičkog, sunčanog rada i nositelj punog sklada između tehnike i etike, mozga i jajeta". ${ }^{30}$ U takvu Šufflayevu pisanju prisutni su svi motivi antimodernizma, kako navodi Grdešić, „polje, dom, Bog, općina,

pokazuje Samuel P. Huntington, da je konzervativizam isključivo ideologija aristokracije i da se definira samo u odnosu na Francusku revoluciju. HUNTINGTON, „Conservatism as an Ideology", 454, 461-470.

26 KRAVAR, Antimodernizam, 154.

27 U jednom će drugom članku iskoristiti istu frazu i pritom objasniti da misli na koncept jednoga od prvih genetičara, Huga de Vriesa, koji je smatrao da nove vrste nastaju naglom promjenom/mutacijom, a ne prirodnim odabirom. „Hugo de Vries”; SMOCOVITIS, „Evolution”, 757; ŠUFFLAY, „Suton zapadne civilizacije, Spengler i Russell, Bergson i Semon”, Pantheon I (1929), br. 3, u: IPS, 288.

28 Na drugom će mjestu reći da su naziv „vijek tame” nadjenuli „materijalistički mudraci” zato što tada nije bilo „petroleja, ni dinamita, ni električnog svjetla, jer je tom periodom pokretala religija”. ŠUFFLAY, „Chevalier Bayard i Einstein”, Književnik (Zagreb) III (1930), br. 12, u: IPS, 296.

29 ŠUFFLAY, „Katolička crkva i Hrvati”, Hrvatsko pravo, 10. 8. 1929., u: IPS, 275. Šufflay se ne poziva na Berdjajeva, ali je svakako moguće da pet godina nakon objave Novoga srednjovjekovlja samo reproducira njegove teze.

30 ŠUFFLAY, „Suton zapadne civilizacije, Spengler i Russell, Bergson i Semon”, Pantheon I (1929), br. 3, u: IPS, 290. 
zajednica, sklad". ${ }^{31}$ Nostalgija za srednjim vijekom očituje se i u Šufflayevu glorificiranju srednjovjekovnoga viteškog etosa. Srednjovjekovnoga viteza Bayarda navest će kao primjer vrlina „vijeka tame”, koje su podrazumijevale požrtvovnost, čast i stegu. Bayard je, piše Šufflay, bio čovjek „bez straha i ljage”, heroj i „nositelj svih vrlina koje u svako doba označuju pravog gentlemana”. ${ }^{32}$ Bayardu suprotstavlja nadolazeću renesansu, koja je slična modernoj dekadenciji i materijalizmu. Bayard se pojavio „kada su, u praskozorju renaissancea, lakajske duše i samoživi oportuniste stali već obilno da se rugaju vjeri, požrtvovnosti, hrabrosti i svijesti dužnosti viteštva". ${ }^{33}$ Srednji je vijek, kaže Šufflay, stvorio cehove, viteške redove, religioznost, žrtvovanje za ideale, poštovanje ženskoga spola, viteško poimanje časti, dužnosti, lojalnosti i hrabrosti. Navedeno je dovoljno, iako je srednji vijek stvorio i mnogo više od toga, da vijek tame bude „svijetao višak prema današnjoj moralnoj tami”. Međutim, „materijalistički mudraci” to ne mogu spoznati jer se to ne može „mjeriti aparatima i ne djeluje na fotografsku ploču" ${ }^{34}$

Šufflay je u dva navoda riječ život napisao velikim slovom, usput tvrdeći da se u vjeri nalazi „silna kinetička snaga prošlosti”. ${ }^{35} \mathrm{U}$ drugom će se članku pozvati na koncept filozofa vitalizma Henrija Bergsona elan vital (životni elan) te je upravo riječ „Život” referenca na Bergsona. Antiracionalistički vitalizam jedno je od obilježja antiprosvjetiteljske tradicije i antimodernizma. Antiprosvjetiteljski mislilac Gustave Le Bon tvrdio je da su se „ne razumom, već najčešće protiv razuma stvorili osjećaji kao čast, samoprijegor, vjera, ljubav prema slavi i domovini, koji su dosad bili veliki pokretači svih civilizacija”. ${ }^{36}$ Čini se da Šufflay glorificira katoličku vjeru i stari poredak ne toliko zato što su oni istiniti, nego stoga što doprinose "Životu”, odnosno zato što je vjera „kinetična snaga”. Henri Bergson govorio je u djelu Stvaralačka evolucija (L'Évolution créatrice) iz 1907. o životnom elanu, tj. životnom instinktu, kao izvoru kreativnosti. ${ }^{37}$ „Dok se inteligencija ophodi spram svih stvari mehanički, instinkt postupa, ako možemo tako reći, organski”, napisat će Bergson izražavajući antimodernističku dihotomiju organsko - mehaničko. Naravno da je u toj dihotomiji organsko superiorno i ono što ima „snagu” jer „inteligenciju karakterizira prirodno nerazumijevanje života”. ${ }^{38}$ On daje prednost intuiciji/

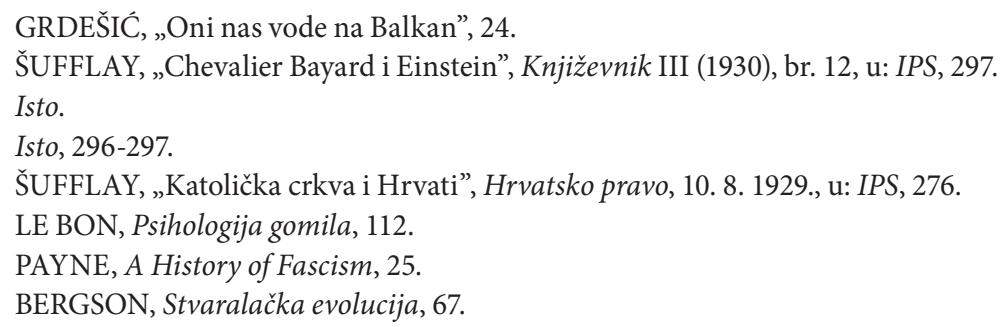


instinktu pred analitičkim, ${ }^{39}$ racionalnim mišljenjem te suprotstavlja nepredvidljivu spontanost znanstvenom determinizmu. Povijest se, prema Bergsonu, razvija potpuno nepredvidljivo i neočekivano, što je smatrao i Šufflay, koji je odbacivao zakonitosti povijesnoga razvoja. Šufflay će napisati da je nemoguće ustanoviti zakonitosti povijesnoga razvoja. Smatrao je da se „historija ne ponavlja točno. Tok njezin organički je rast. Uvjetuju ga poglavito krv i zemlja, vis a tergo ili životni elan, pa klima i plastika tla" ${ }^{40}$

I drugi antiprosvjetiteljski mislioci međuratne generacije i kasnoga XIX. stoljeća zagovaraju vitalizam te je za njih religija korisna zbog pragmatičnih razloga, a ne sama po sebi. Ona nema inherentnu vrijednost. Spengler je pak racionalizmu prosvjetiteljstva suprotstavljao „religijsku kreativnost” povezanu s instinktima te s povezanošću pojedinca i zajednice. Religija i vjera bile su korisne i poželjne jer su dio iskonske tradicije. Mjerilo više nije Bog, nego vitalnost. ${ }^{41} \mathrm{Da}$ je riječ o vitalističkom novom dobu dokazuje Šufflayeva eksplikacija „četvrtoga doba” u drugom članku, u kojem kaže da početak novoga doba obilježava „okret prema ispitivanju nedovoljno poznatih, dakle okultnih sila”. ${ }^{42}$ Novo doba pripremit će „stvaralačka klica hipnotičkom snagom”. U novom će dobu duhovnost imati veću vrijednost. ${ }^{43}$ Šufflay objašnjava da se „bijela znanost pomalo posvema odvraća od borniranog materijalizma i priklanja vitalističkom stanovištu tj. tezi da u Životu rade sile, koje nisu od ovog, materijalnog svijeta. Život izgleda meni poput iskre, u kojoj se sastaju dva kozmosa”. ${ }^{44}$ Šufflay ne zagovara univerzalističko kršćanstvo jer je ono jedino „ispravno”. On čak iskazuje divljenje spram duhovne indijske filozofije. Moral vjerojatno za njega nije univerzalan, nego kulturno uvjetovan, što je tipičan

\footnotetext{
39 Šufflay će pejorativno reći da je „bijela rasa” „rob intelekta”. ŠUFFLAY, „Britansko Carstvo”, Obzor (Zagreb), 9. 5. 1926., u: IPS, 40.

40 ŠUFFLAY, „Hrvatska krv i zemlja”, Starohrvatska prosvjeta (Zagreb/Knin) I (1927), u: IPS, 71. Time Šufflay odbacuje i Spenglerovu revitalizaciju antičkoga kružnog/cikličkog poimanja povijesti, ali i kršćanstvom inspiriranu linearnu/teleološku povijest, što će poslije zastupati Kant, Herder, Schelling, Fichte, Hegel, Marx i mnogi drugi. GROSS, Suvremena historiografija, 21-34, 38, 111; FUKUYAMA, Kraj povijesti, 115-144.

${ }_{41}$ STERNHELL, The Anti-Enlightenment Tradition, 356-358. Ipak, nisu svi antiprosvjetiteljski mislioci smatrali da je kršćanstvo izvor snage i zato pozitivna pojava. Primjerice, Vilfredo Pareto u eseju Uspon i pad elita iz 1901. izrazito negativno piše o kršćanstvu, predstavljajući kršćanstvo svojega doba samo kao socijalizmu suparničku (slabu) religiju na zalazu snaga koja slabi vladajuće svojim milosrđem. S druge strane cijeni nacionalizam kao „jedini oblik otpora socijalizmu koji danas postoji u Francuskoj” iako kaže da, čitajući francuske nacionaliste, dvoji „jesu li svi ti ljudi zdrave pameti”. Usprkos, kako kaže, njihovim „blesavim” riječima, pitanje otpora socijalizmu je „vrlo ozbiljno pitanje od prave vrijednosti”. Dakle, nacionalizam je za njega instrumentalno koristan zbog snage. PARETO, Uspon i pad elita, 28-29.

42 ŠUFFLAY, „Suton zapadne civilizacije, Spengler i Russell, Bergson i Semon”, Pantheon I (1929), br. 3, u: IPS, 288.

$43 \quad$ Isto, 289.

$44 \quad$ Isto, 288-289.
} 
stav dijela antiprosvjetiteljskih intelektualaca. Spengler će također reći da postoji onoliko različitih moralnosti koliko ima kultura te za njega ne postoje univerzalna kultura i univerzalna istina. ${ }^{45}$ Štoviše, Šufflay Zapadu suprotstavlja Istok, koji ima brojne kvalitete na koje Šufflay gleda sa simpatijom. Zapad će te kvalitete oživiti u „novom dobu”. Zapad je za Šufflaya rob intelekta koji je izgradio industrijalizirani Zapad te je „u službi mašina, gotovo napustio jedinu pravu industriju, obrađivanje polja”. ${ }^{46}$ Suprotstavljen Zapadu u tom je pitanju Istok, prije svega Indija i Kina. „U tim zemljama obrađivanje polja jedina je prava industrija; pravda i sreća vrijede im više od poznavanja prirodnih sila." ${ }^{37}$ Dakle, Istok posvećuje veću pozornost duhovnom nego materijalnom, za razliku od Zapada. Ondje, ističe Šufflay, postoji „sklad između ljudske kulture i ljudske nature" te ne postoji ,jaz između religije i znanosti”, ali to ne zanima ohologa bijelog čovjeka. ${ }^{48}$ Zapadnjak je individualac i pokreće ga egoizam, dok je „istočnjačka socijalna jedinica dom, životni princip mu je samozataja, požrtvovnost za dobro općine”. Za razliku od zapadnjaka, koji „teži za znanošću i vlašću”, istočnjak teži za „mudrošću i unutarnjim mirom”. "Za Ž Šuflaya je individualizacija negativan trend, a istočnjački kolektivizam poželjno društveno obilježje koje bi Zapad trebao revitalizirati.

Šufflay koristi esencijalističku binarnu dihotomiju koja svijet dijeli na dvoje - na Istok i Zapad, koji su u perpetualnom sukobu. Šufflayevo je razmišljanje primjer orijentalizma. Za Edwarda W. Saida orijentalizam je „način mišljenja zasnovan na ontološkoj i epistemološkoj distinkciji između 'Orijenta' i (većinom) 'Okcidenta”" ${ }^{50}$ Said smatra da je Orijent „Drugi” koji je „pomogao da se Europa (ili Zapad) odredi kao njegova oprečna slika, zamisao, oprečna osobnost i oprečno iskustvo". ${ }^{51}$ Za razliku od Saidova Okcidenta, koji je Orijent definirao iz superiorne pozicije smatrajući ga inferiornim, Šufflay ne pridaje Istoku samo negativne osobine. Istok i Zapad nalaze se u opreci, ali kao što je primjetno, on iskazuje izrazito poštovanje prema Indiji i Kini. „Istok” koji će biti isključivo pejorativno opisan bit će Balkan, točnije Srbi, koji su za Šufflaya eksponent Istoka i nositelj negativnih osobina, o čemu će biti riječi poslije. Saidova matrica upotrebljiva je u Šufflayevu slučaju jer Orijent i Okcident uistinu jesu ontološki potpuno različiti, a čini se da su unutar sebe homogeni. Tako Šufflay nikad ne diferencira različite kulture, načine razmišljanja i mentalitete na Istoku niti ga precizno određuje, kao ni Zapad.

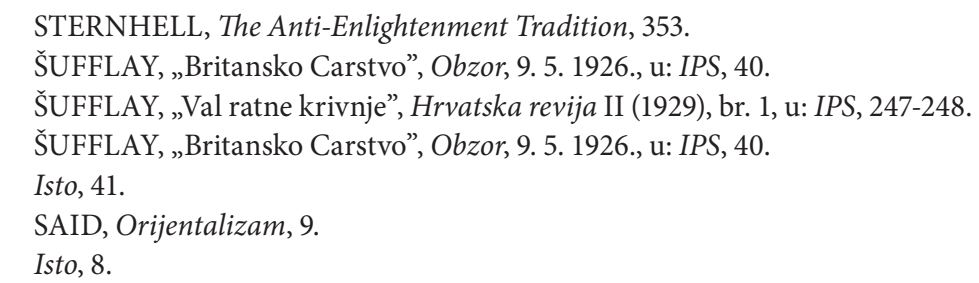


Spomenuta Šufflayeva fraza „rob intelekta” njegov je napad na racionalizam, čest kod antiprosvjetiteljskih intelektualaca. Spenglerov koncept „degeneracije” iz kulture u civilizaciju, odnosno iz prevlasti duhovnoga u prevlast materijalnoga, koji počinje nakon industrijske revolucije, korespondira s prevlašću razuma, odnosno robovanjem intelektu. Kulturu od civilizacije razlikuju „snaga pojedinaca suprotstavljena masi, kreativnost suprotstavljena dekadenciji, genijalnost suprotstavljena racionalnosti”. ${ }^{52}$ U Propasti Zapada Spengler će napisati da je kultura „živo i produhovljeno tijelo”, a civilizacija je „mumija tog istog tijela”. ${ }^{3}$

\section{Milan Šufflay i hrvatska nacija}

Intelektualni temelj za uopće formiranje ideje nacije dolazi u prosvjetiteljstvu, kada se stvara ideja narodnoga suvereniteta, odnosno suvereniteta nacije/naroda ispred suvereniteta kralja, čiji je suverenitet $u$ tadašnjoj paradigmi dolazio izravno od Boga. Prosvjetiteljski filozofi Locke, Hobbes, Rousseau, Montesquieu i drugi konceptom prirodnih i neotuđivih prava uzdrmali su taj koncept i stvorili naciju jednakih građana koji su nositelji suvereniteta, što će biti iskazano u Deklaraciji o pravima čovjeka i građanina i američkom Ustavu. ${ }^{54}$ Tako su autori prve enciklopedije, prosvjetitelji Diderot i Alembert, definirali da pod naciju spadaju ljudi koji žive na određenom teritoriju i imaju istu vlast, a David Hume rekao je da je nacija skup pojedinaca. ${ }^{55}$ To je takozvani liberalni, građanski nacionalizam, u kojem etnički i lingvistički čimbenici nisu bitni za određivanje nacionalne pripadnosti. Međutim, u romantizmu se pojavilo drukčije gledište, koje će postati predominantno na njemačkom govornom području, ali i u istočnoj i jugoistočnoj Europi. Utjecajni romantičarski filozof Johann Gottfried Herder držao je da svaki narod ima svoj posebni „duh” (Volksgeist). Taj se duh najbolje izražava u jeziku zajednice, koji je isključivi kriterij za određivanje nacionalne pripadnosti. ${ }^{56}$ Zato su romantičarski nacionalisti tragali za „pravim govorom naroda”, koji su nastojali promicati u književni standard, što su primjerice činila braća Grimm ili Vuk Karadžić. ${ }^{57}$ Narodna stranka Josipa Jurja Strossmayera i Franje Račkog zastupat će etnolingvistički nacionalizam, pri čemu se etnos temelji na zajedničkom jeziku, a Ante Starčević i Stranka prava zastupat će građanski nacionalizam. Franjo Rački u tekstu „Jugoslovjenstvo”, programskom spisu Narodne stranke objav-

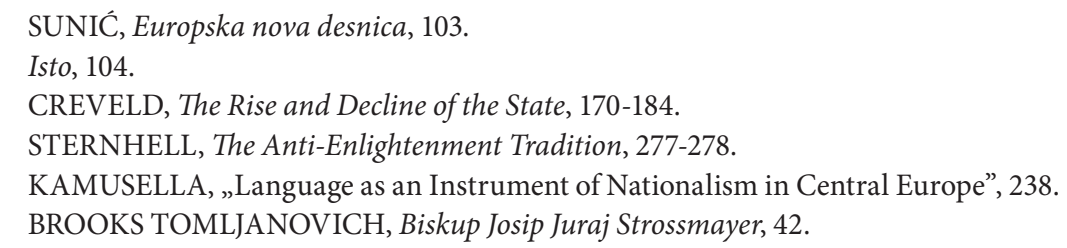


ljenom 1861., ističe da je jezik „duša naroda” te da je jedinstveni standardni jezik uvjet stvaranja nacije. ${ }^{58}$

Identitet, pa tako i nacionalni, relacijski je te se formira u odnosu na „Drugoga” ${ }^{59}$ Kako ističu Bucholtz i Hall, identitet je „društveno pozicioniranje sebe i drugoga”. Iz toga se potvrđuje da je identitet relacijski te se formira u odnosu na drugoga. ${ }^{60}$ Riječima sociologa Pierrea Bourdieua, „društveni identitet leži u razlici” ${ }^{61}$ Za razliku od jezika, katolička vjerska pripadnost Hrvata nije mogla biti korištena kao distinktivni element spram Mađara i Nijemaca, koji su pretežito katolici, ili isključivo katoličkih Talijana. ${ }^{62}$ Iako je čelnik Narodne stranke Josip Juraj Strossmayer bio katolički biskup, a Franjo Rački svećenik, nikad nisu smatrali da je vjera dio nacionalnoga identiteta, a u Šufflayevu će vremenu upravo katolička vjera biti isticana kao distinktivno obilježje spram Srba u vjerskom i civilizacijskom smislu (pripadanje Zapadu). Rački kaže da su Jugoslaveni razdijeljeni na tri vjere (katoličanstvo, islam i pravoslavlje), ali da to nije prepreka za narodno jedinstvo jer postoje druge nacije koje su plurikonfesionalne te navodi katoličko-protestantske Nijemce, Mađare i Čehe. ${ }^{63}$ Suosnivač Stranke prava i poslije dugogodišnji vođa Ante Starčević bio je „učenik” prosvjetiteljstva i Francuske revolucije, pa shodno tome i pobornik građanskoga nacionalizma. Uklopivši prosvjetiteljsku tradiciju u hrvatsko državno pravo, tvrdio je da su u krajevima koji su povijesno bili dijelovi Hrvatske jedino Hrvati politički subjekt i jedina nacija jednakopravnih građana, kao što su u Francuskoj Francuzi, a ne postoji primjerice bretonska nacionalna manjina. Taj povijesno hrvatski teritorij za Starčevića je obuhvaćao područje od Soče do Marice, pa su Slovenci „alpski Hrvati”, a Srbima se negira postojanje. Budući da je njegov nacionalizam bio građanski, vjerska identifikacija nije imala ulogu u pripadnosti hrvatskoj naciji. ${ }^{64}$

U prvoj polovini XX. stoljeća skupina hrvatskih intelektualaca formirat će drugačiju sliku hrvatske nacije. Za njih će, kako kaže Stipe Kljaić, „bit hrvatskoga nacionalizma” biti „protujugoslavenstvo, protusrpstvo i protukomunizam" ${ }^{65} \mathrm{U}$ takvu razvijanju hrvatskoga nacionalnog identiteta nasuprot srp-

\footnotetext{
58 RAČKI, „Jugoslovjenstvo”, 278.

59 BUCHOLTZ, HALL, „Identity and Interaction”, 585.

$60 \quad$ Isto, 586.

61 BURKE, What is Cultural History?, 57.

62 BROOKS TOMLJANOVICH, Biskup Josip Juraj Strossmayer, 44.

63 RAČKI, „Jugoslovjenstvo”, 281.

64 GROSS, Izvorno pravaštvo, 15-37. U članku „Bi-li k Slavstvu ili ka Hrvatstvu?” iz 1867. Starčević se obračunava s etnolingvističkim poimanjem nacije ilirskoga pokreta i Narodne stranke te zaključuje da se u Francuskoj zna da su i Gaskonjac i Bretonac Francuzi, a da u toj zemlji „za kerstni list ili za pašuš njegovih prašukunbabah, za doznati jezik [...] rodna mesta, nitko nepita”. STARČEVIĆ, „Bi-li k Slavstvu ili ka Hrvatstvu?”, 40-41.

65 KLJAIĆ, Nikada više Jugoslavija, 394.
} 
skom, što se događa zbog iskustva srpske hegemonije u Kraljevini Jugoslaviji, važnost hrvatskoga jezika za hrvatski identitet umanjuje se jer je srpski jezik sličan hrvatskom, a u prvi se plan stavljaju drugi elementi nacionalnoga identiteta. Najvažniji od tih intelektualaca, koje Višeslav Aralica naziva „hrvatskim nacionalistima" da bi ih razlikovao od intelektualaca povezanih sa seljačkim pokretom Stjepana Radića, jesu Milan Šufflay, Ivo Pilar i Filip Lukas. ${ }^{66} \mathrm{Za}$ Šufflaya je hrvatska nacija organska i primordijalna. Ona postoji od „iskona”. Riječima Zorana Kravara, Šufflay vjeruje „u neprekinute nacionalnopovijesne longitudinale”. ${ }^{67}$ Šufflay će upotrijebiti i „nove” rasne, civilizacijske i geografske argumente koji su ključni za „dušu” hrvatske nacije, koji su, naravno, svi izravno suprotstavljeni jugoslavenskom nacionalnom identitetu, a minorizirat će važnost jezika za konstituiranje nacije. ${ }^{68}$ Posao nam olakšava činjenica da je Šufflay eksplicitno definirao što je to za njega nacija:

„Glavni unutarnji faktori za stvaranje ovakove kolektivne ćelije višeg reda jesu srodna krv, plastika tla, zajedničko pamćenje kolektivnih boli i radosti kroz dugi niz generacija, dakle rasni, geografski, kulturni i historički momenti. ${ }^{69}$ Zajednički jezik sam po sebi nipošto ne stvara naciju. Kroz dugi niz vjekova jezik čak razbija nekad jedinstvena plemena, kako to uči glotologija uopće, a indoevropska komparativna filologija napose. Golemo područje engleskog jezika smjesta bi se raspalo barem na tri zasebna jezika, kad bi nestalo literarne tradicije i kad bi se napustila etimologija u pisanju. Svaka nacija imade svoj vlastiti penši, svoje zasebne biološke odlike i mane, a prema tomu postoji i penši njihova saobraćajnog organa, jezika [kurziv dodao T. K.]."

Šufflay je uveo kineski pojam penši, za koji kaže da je neprevodiv, ali s obzirom na upotrebu pojma može se zaključiti o čemu je riječ. Kaže da je šepurenje paunov penši, a mravinjak ima komunistički penši. Taj bismo termin dakle mogli prevesti kao bit, duh ili narav. ${ }^{70}$ Iako je minorizirao ulogu jezika, kaže da svaki jezik ima svoj penši. Tako srpski i hrvatski jezik imaju različit penši, što je očiti postupak ikonizacije. Ikonizacija je, prema Irvine i Gal, postupak kojim se lingvističke značajke određene društvene skupine projiciraju i prikazuju kao da čine inherentnu narav te skupine. Ta projekcija postaje „ikonična reprezentacija" skupine. ${ }^{71}$ Kako objašnjava Šufflay:

\footnotetext{
66 ARALICA, Kmet, fiškal, hajduk, 331-443.

67 KRAVAR, „Revizionizam tvrdo ukoričen”, 14.

68 BARTULIN, „The Anti-Yugoslavist Narrative”, 87.

69 U drugom će članku to formulirati na sličan način te će reći da su elementi „srodna krv, plastika tla, zajedničko pamćenje boli i radosti kroz dugi niz generacija, dakle rasni, geopolitički, kulturni i historijski momenti”. ŠUFFLAY, „San i java”, Pantheon I (1929), br. 5, u: IPS, 291.

70 ŠUFFLAY, „Pen-Ši: Hrvatskog jezika”, Obzor, 19. 7. 1928., u: IPS, 87.

71 IRVINE, GAL, „Language Ideology and Linguistic Differentiation”, 35-39.
} 
„Svoje penšije imadu i hrvatski i srpski jezik. Jasno je vidljiv taj penši u narodnim pjesmama, koje je vanredno teško prevoditi na drugi jezik. [...] Ono za čim narodna duša uporno žene, a što se ne dade realizirati na javi, to se očituje u mitu, u ciklu narodnih pjesama. U takovom ciklu sadržan je stoljetan san jedne nacije. A nacije sanjaju različito pak je i snena odora takovih pjesničkih tvorevina teško prevodljiva. Asocijacije obavljaju se ovdje u jakim skokovima kao u individualnim snovima. Imade tu izraza, atributa i metonimija, koji u tuđem jeziku zvuče skroz-naskroz nezgrapno." 72

Dakle, duh jezika izražava se u neprevodivosti nekih termina i različitim „snovima”, što uzrok ima u organskoj uklopljenosti pojedinca u „nacionalno biće”. Zato određene termine mogu razumjeti samo pripadnici te organske zajednice. U istom će se članku referirati na netom objavljenu knjigu zoologa Miroslava Hirtza Rječnik narodnih zooloških naziva, za koju kaže da može poslužiti „kao predmet studija poredbenoj psihologiji naroda”. ${ }^{73}$ Za Šufflaya su različiti narodni nazivi za poskoka (Vipera ammodytes) u Vrapču kod Zagreba i srpskim predjelima Podrinja dokaz „goleme razlike u mentalnim asocijacijama Srba i Hrvata”. Narod u Vrapču za poskoka koristi naziv brezovača jer je poskok sivkast kao kora breze, a u srpskim se krajevima koristi naziv džerevdan zato što je poskok išaran kao duga puška kremenjača, džerevdanka. ${ }^{74}$ Šufflay time upozorava na militarističku i nasilnu narav Srba jer im je asocijacija na poskoka puška. Vratimo se na Šufflayevu definiciju nacije. Komponente nacije su rasni, geografski, kulturni i historički „momenti”. Šufflay svaki od tih „momenata” suprotstavlja „Drugom”, odnosno Srbima. On vjeruje da se seoba Slavena na jugoistok Europe zbivala u dva navrata. „Hrvati i Srbi podjednako su, na Balkanu preslojili nešto starije i posve srodno slovensko pučanstvo. Ali nijesu primili jednaku natruhu inorasne krvi [kurziv dodao T. K.]." Koje je to stanovništvo „inorasne” krvi koje Hrvate već u ranom srednjem vijeku razdvaja, u rasnom pogledu, od Srba? Na Hrvate je, drži Šufflay, u većoj mjeri utjecao avarski element, a njihov se utjecaj očituje u tituli ban, koja dolazi od avarskoga izraza bajan. Srbi su na jugu primili više „ilirsko-arbanaske krvi”. Romanski su pak utjecaj Hrvati dobili preko dalmatinskih gradova, a Srbi preko Duklje, ali je taj udio, smatra Šufflay, neznatan. ${ }^{75}$ Šufflay ne opisuje Slavene negativno za razliku od nekih drugih nacionalista iz toga perioda, koji su zagovarali iransku teoriju o podrijetlu Hrvata (npr. Stjepan Sakač). On Slavene opisuje kao mirotvorno, pobožno, sjedilačko pučanstvo koje tlače nomadski narodi. Štoviše, današnji su Hrvati naslijedili pozitivne karakteristike Slavena:

\footnotetext{
72 ŠUFFLAY, „Pen-Ši: Hrvatskog jezika”, Obzor, 19. 7. 1928., u: IPS, 87-88.

73 Isto, 90.

74 Isto, 91.

75 ŠUFFLAY, „Hrvatska krv i zemlja”, Starohrvatska prosvjeta I (1927), u: IPS, 74.
} 
„Slavenska sesilnost pretvara se u vjernost prema domovinskoj grudi, slavenska mukotrpnost u čuvstvo lojalnosti. Na pograničnom teritoriju niču 'graničari’ i to ime zadugo postaje sinonim za Hrvate. [...] Biološka pozadina ove svijesti pijetet je prema mrtvim i dužnost prema još nerođenim generacijama. Uz suradnju komponente 'bogonosca' ta se svijest u današnjim danima kristalizira u martirsku borbu za načela čovječnosti." 76

Slaveni ipak nisu bili sposobni stvoriti državu zbog pacifističke naravi, ali su Hrvati imali avarski utjecaj koji je hrvatstvu, zajedno sa slavenskim utjecajem, dao najbolje osobine. Avari daju Slavenima „državnu sadržinu i formu, ali baš djelomično čisti slavenski temelji ove države i aktivno sudjelovanje slavenskog življa u njenoj konsolidaciji najbolje tumače brzi, zagonetni i golemi uspjeh na Balkanu" ${ }^{77}$ Šufflay je zapravo preuzeo teoriju češkoga povjesničara Jana Peiskera, koji je smatrao da su Slaveni organizacijski inferiorni te da je svaku „slavensku” državu utemeljio germanski ili altajski vodeći društveni sloj. U hrvatskom su slučaju to bili Avari. ${ }^{78}$ Ipak, Šufflay opisuje Slavene u pozitivnom svjetlu, zbog čega će ga Stjepan Buć, jedan od osnivača Hrvatske nacionalsocijalističke stranke, svrstati u „slavomane”. ${ }^{79}$ Međutim, turska su osvajanja imala veliki udio u rasnom oblikovanju Srba, drži Šufflay. Zbog toga su postali rasno i kulturno istočnjački narod, sa svim negativnim karakteristikama koje za Šufflaya ima istok Europe. Slaveni su za Šufflaya „sesilna rasa koja bez poriva nomadske krvi posvuda poput kitajske [kineske, op. T. K.] silnom snagom lijepi uz tlo". S druge strane Vlasi/Cincari, koji se sele uslijed osmanske ekspanzije, potpuno su drugačiji. Vlasi koji dolaze i u hrvatske krajeve „u žilama svojim nose one staru vagilnu krv i onakav mentalitet, kakav im je nametnuo stoljetni intenzivni grčki utjecaj, koji je bio vazda snažan i u Turskoj Carevini". ${ }^{80}$ Šufflay drži da je kod Srba prevladao taj vlaški element nad slavenskom bazom, a shodno tome Srbi su poprimili takav mentalitet. Šufflay se poziva na studiju O Cincarima. Prilozi pitanju postanka naše čaršije Dušana Popovića te navodi da „tjelesne osebujnosti Cincara, koji su se vrlo rado ženili međusobno, jesu nos i oči. Stevan Sremac kaže za grčku školu, da je ondje 'svaki đak pola dete, a pola nos'. Cincari su imali vrlo karakteristične, duboko upale oči, iz kojih se vidi bistrina, razboritost, odlučnost, nadmoć, ali i lukavstvo i podmuklost”. Usto je osobina Cincara „nevjerojatna sebičnost, grčko-cincarska drobna pamet bez milosrđa i gostoljublja. Osobito se cijene kod njih i smatraju za najpametnije lukavi ljudi. Opće im je shvaćanje, da se

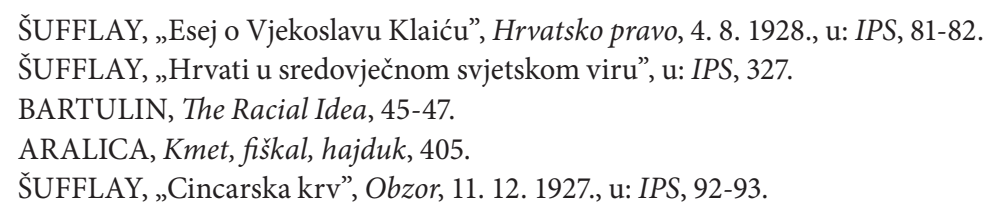


inovjercu može učiniti svako zlo a da to ne bude grijeh". ${ }^{81}$ Šufflay je smatrao da je cincarski utjecaj na mentalitet i rasni sastav Srba velik. „Mi Hrvati [...] temeljito na vlastitoj koži osjećamo da cincarska krv, kako se je kroz stoljeća svarila u bizantinsko-turskoj retorti, i te kako još danas živi u Beogradu”, napisat će Šufflay. ${ }^{82}$ Srbi su dakle predstavnici bizantinsko-turske civilizacije, a Hrvati su zapadni narod.

Geografske razlike Hrvata i Srba također su nepomirljive. Za Šufflaya je geografija „moćniji faktor kod historičkog stvaranja država, nego i sam pojam nacije ili historičkog naroda. Prve rade poput malih laguma na mahove, ove druge polagano, ali neodoljivo poput orijaškog parnog valjka”. ${ }^{83} \mathrm{Na}$ Balkanu, drži Šufflay, postoje tri geografska područja: podunavsko, jadransko i gorsko-kontinentalno. Hrvati uglavnom pripadaju jadranskom i podunavskom području. Zbog prvoga su primorska nacija, a zbog potonjega imaju „protubalkanski karakter”. S druge strane Srbi su sasvim „kontinentalna nacija”. ${ }^{84}$ Različita geografija utječe i na različit mentalitet stanovništva. Tako seljaštvo iz nizinskih predjela uz Savu, Dravu i Moravu ima „drugu dušu i druge snove” u usporedbi sa stočarskim stanovništvom planinskih krajeva. Šufflay zaključuje da Kraljevina Srba, Hrvata i Slovenaca obuhvaća „isječke iz sva tri područja Balkana”, što je jedan od uzroka njezine disfunkcionalnosti. Naime, „od triju geopolitičkih područja ne da se obrazovati zdrava, centralistički uređena država". 85

Možda najvažnija distinkcija jest ona „kulturna”, odnosno civilizacijska. Hrvati su Antemurale Christianitatis katoličkoga Zapada i graničarski narod koji se tijekom povijesti borio s drugim nezapadnim civilizacijama, čiji su predstavnici, uz ostale, i Srbi. S kulturnim „momentom” povezan je i „historički”. Šufflayeva je nacija organska zajednica koja veže mrtve, žive i buduće generacije. To nije bio usamljen pogled na naciju u Šufflayevo doba, iako se Šufflay konkretno ne poziva na autore koji su formulirali slične ideje. $\mathrm{Za}$ intelektualce antiprosvjetiteljske provenijencije kasnoga XIX. i prve polovine XX. stoljeća nacija nije bila zbroj individualnih građana, što je izravno povezano s napadom na individualizam i davanjem primata zajednici. Za ideologa integralnoga nacionalizma Mauricea Barrèsa pojedinac je nastavljač svojih predaka, o njima ovisi te je proizvod sredine, odnosno kulture koja ima svoju „narodnu dušu”. Svaki je pojedinac organski povezan sa „zemljom i mrtvima”. Barrès je, kao i niz već predstavljenih intelektualaca, smatrao da

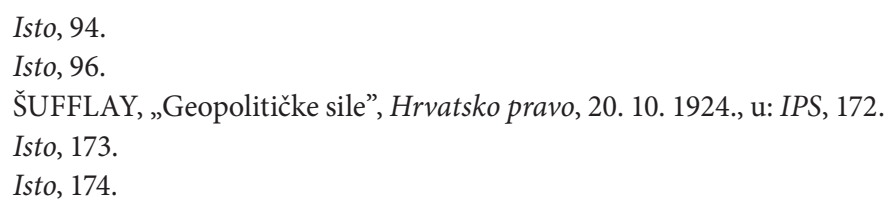


je racionalizam obilježje onih koji su „iščupani” iz korijenja kojem pripadaju, onih koji ne pripadaju vjekovnoj zajednici. ${ }^{86} \mathrm{Nacija}$ je postala živi organizam, a kulturno deterministička stajališta postala su u tom periodu posve uobičajena. ${ }^{87} \mathrm{Na}$ Barrèsovo djelo nastavlja se Charles Maurras, osnivač političkoga pokreta Action Française. Maurrasov pogled na naciju sličan je Barrèsovu, ali i Šufflayevu. Reći će da Francuska nije nastala društvenim ugovorom na voluntarističkoj osnovi te da ne obuhvaća samo četrdeset milijuna živih, nego i milijardu mrtvih. Za Maurrasa nacija nije skup pojedinaca koji glasaju, nego je nacija obitelj. ${ }^{88}$ Slične je ideje iznosio i Filip Lukas, za koga se „narod sastoji od prošlih i sadašnjih i budućih naraštaja". ${ }^{89}$ Kako ističe teoretičar razvoja nacija Anthony D. Smith, „organski nacionalizam drži da se svijet sastoji od prirodnih nacija i da je tako od pamtivijeka; nacije su temelj povijesti i glavni akteri u povijesnoj drami; da su nacije i njihovi karakteri organizmi koji se mogu lako prepoznati prema svojim kulturnim razlikama".90 Šufflay će izraziti ideju sličnu Barrèsovoj i Maurrasovoj:

„U svakom pojedincu mnemički žive svi njegovi pređi, a u jednoj živoj generaciji sve generacije mrtvih?! Jugoslavenska ideja ne može biti kinetički živa. Nje nema u podsvijesti današnjih južnih Slavena, jer nije nikada živjela u liniji predaka sadašnje hrvatske i srpske generacije. Nad ponorom dvaju svjetova, iznad sukoba živih milijuna bije se sablasni boj milijarda mrtvih predaka. ${ }^{.91}$

\footnotetext{
86 STERNHELL, The Anti-Enlightenment Tradition, 316-318. Maurice Barrès (1862. - 1923.), francuski književnik i političar, izabran je 1889. u Zastupnički dom kao bulanžist (pristaša generala Georgesa Boulangera) zagovarajući u kampanji „nacionalsocijalizam” s antisemitskim parolama. Za vrijeme Dreyfusove afere (1894. - 1906.), koja je oštro podijelila francusko društvo, Barrès se ističe kao antidrajfusovac. Kao zagovornik organskoga nacionalizma, snažno utječe na krajnje desni monarhistički pokret Action Française Charlesa Maurrasa iako sam nije bio monarhist. STERNHELL, „National Socialism and Antisemitism”.

87 STERNHELL, The Anti-Enlightenment Tradition, 324.

88 Isto, 328-329. Charles Maurras (1868. - 1952.), francuski književnik i političar, suosnivač i ideolog francuskoga monarhističkog pokreta Action Française, koji je osnovan 1899. godine. Krajem XIX. i početkom XX. stoljeća antisemit Maurass ističe se kao antidrajfusovac. Njegov se pokret zalagao za ponovnu uspostavu katoličke monarhije, a Maurras je smatrao da katoličanstvo treba imati veću ulogu u Francuskoj iako sam nije bio vjernik, nego je, kao i dio antiprosvjetiteljskih mislilaca, smatrao da vjera ima važnu ulogu za uspostavu i održavanje poretka. Ipak, papa Pio XI. 1926. osudit će Maurrasa i pokret Action Française. Antimodernist, zagovornik integralnoga nacionalizma te oštar kritičar liberalizma i demokracije, Maurras utječe na mnoge fašističke pokrete. Po oslobođenju Francuske zbog kolaboracije s vlastima Višijevske Francuske osuđen je na doživotni zatvor. Opširno o Maurrasovu životu i stvaralaštvu vidi: NOLTE, Fašizam u svojoj epohi, 39-150.
}

89 ARALICA, Kmet, fiškal, hajduk, 391.

90 SMITH, Nacionalizam i modernizam, 150. Ukrajinski povjesničar Oleksandr Zaitsev kaže da integralni nacionalizam kao „forma autoritarnoga nacionalizma”, za razliku od liberalnoga nacionalizma, „smatra naciju organskom cjelinom i zahtijeva bezrezervno podređivanje pojedinca interesima njegove ili njezine nacije”. ZAITSEV, „Ukrainian Integral Nationalism”, 13.

${ }_{91}$ ŠUFFLAY, „Hrvati nisu kunići”, Hrvatsko pravo, 20. 9. 1928., u: IPS, 236-237. 
Šufflay drži da državne tvorevine trebaju biti izraz narodne svijesti, a narodni vođe odraz organske povezanosti sa „zemljom i mrtvima”. Smatrao je da su vođe naroda „predstavnici najdubljeg, uzdužnog i poprečnog sloja kolektivnih čežnja, eksponenti narodnog sna na javi”. ${ }^{92}$ Prava su manifestacija narodne duše, a shodno tome i pravi narodni vođe, Nikola Pašić, mađarski premijer István Bethlen, Benito Mussolini i Stjepan Radić. ${ }^{93}$ Za Šufflaya je iznimno važno povijesno sjećanje određenoga naroda, a povijesna memorija ima nevjerojatnu moć. Šufflay prihvaća odbačenu teoriju organske memorije evolucijskoga biologa, lamarkijanca Richarda Semona, koji je smatrao da se memorija prenosi s generacije na generaciju. ${ }^{94}$ Ono što je za Mađare kruna sv. Stjepana, za Srbe sjećanje na cara Dušana, to je za Hrvate memorija i sjećanje na kraljeve Zvonimira i Tomislava. Povezano s antiprosvjetiteljskim razmišljanjem, mit, a ne razum, ono je što daje snagu narodu. Mitovi, kako ističe Joanna Overing, imaju ulogu pružanja smisla i svrhe određenoj zajednici te ulogu u stvaranju kohezije, kao i pri legitimiranju postojećega, tradicionalnoga društvenog poretka. Zbog toga je nebitno jesu li oni istiniti ili ne. ${ }^{95}$ Kako kaže George Schöpflin, bitan je sadržaj mita, a ne njegova povijesna točnost. Mitovi su dio „mreže komunikacije” zajednice i stvaraju koheziju zajednice, odnosno „kozmos iz kaosa”. ${ }^{96}$

Tako otprilike mitove promatra i Šufflay, on više govori o pragmatičnoj koristi nekoga mita, koji je istinit ako ljudi u njega vjeruju. Može se reći da Šufflay prihvaća tzv. Thomasov teorem, koji glasi: „ako ljudi definiraju situaciju kao realnu, ona je realna u svojim posljedicama." ${ }^{97} \mathrm{U}$ skladu s tim, istiniti su mitovi o Kraljeviću Marku, Zvonimiru i Tomislavu. Hrvati i Srbi imaju potpuno različito povijesno sjećanje, a Jugoslaveni nemaju povijesno sjećanje, pa ne mogu imati ni zajedničku državu. Šufflay će ponovno za opravdanje svoje ideologije koristiti znanstveni diskurs i pozivati se na znanstvene autoritete. Navodi da je Sigmund Freud dokazao „da se snovi temelje na principu podsvjesnog pamćenja i na principu ispunjenja najdubljih, mozgu često posve sakrivenih želja". ${ }^{98}$ Šufflay Freudovu teoriju, koja se odnosi na snove pojedine osobe, prenosi na narode, koji imaju zajedničke snove. Pritom se poziva na Freudova učenika, psihoanalitičara Otta Ranka, i njegovo djelo Mit o rođenju heroja. Kaže da je Rank pokazao da su „mitos i narodna priča građeni po principima individualnih snova, da su mit i epopeja zapravo stoljetan san od-

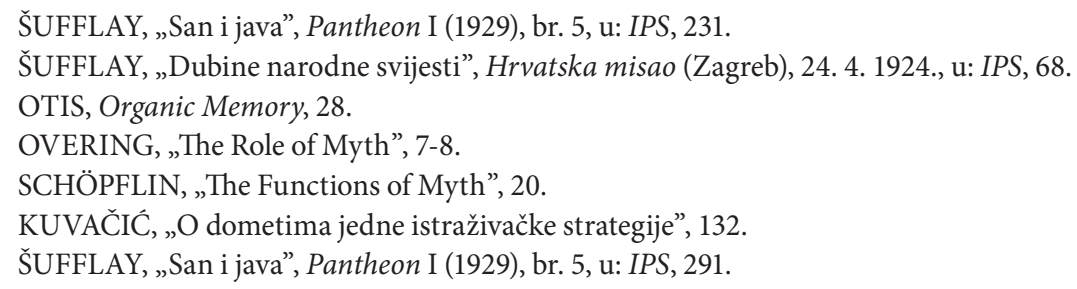


nosnog naroda. Sve, što se duboko usjeklo u kolektivno pamćenje, sve, za čim je narodna duša čeznula i čega nije mogla realizirati na javi, to se je izradilo u mitu ili ciklu pjesama oko kojeg snenog narodnog heroja". ${ }^{99}$ Primjer je takva narodnoga heroja Kraljević Marko, koji je, prema Šufflayu, neznatna povijesna ličnost, ali je stvarnost jer živi u mitovima srpskoga naroda te je izraz srpskih nacionalnih težnji. ${ }^{100}$ Zato je „živa” i snažna ideja o Dušanovu carstvu koja se usjekla u svijest srpskoga naroda, pa je samim time i stvarna. Postoji „historijska živa sila Dušanova carstva”, reći će Šufflay. Smatrao je da kod Hrvata, nasuprot ideji o Dušanovu carstvu, mađarskoj ideji Stjepanove krune i talijanskom starorimskom imperijalizmu, mora postojati ideja Tomislavove države. ${ }^{101}$ Prema Šufflayu, postoje tradicija, povijesno iskustvo i zajednički život naroda koji uvjetuju „prirodne” državne formacije. On je konzervativac, zalaže se za očuvanje postojećega i evolucionizam jer konzervativci „retrospekcijom podržavaju kontinuitet, a time osiguravaju stalan napredak”. ${ }^{102}$ Jugoslavija je umjetna tvorevina koja od dvije potpuno oprečne povijesti, one hrvatskoga i one srpskoga naroda, ideje Dušanova carstva i Tomislavove države, nastoji stvoriti umjetnu zajedničku državu, koja nije organska, nego je načinjena. Zato će Šufflay dva članka usmjerena protiv zapadnih zagovaratelja Jugoslavije nasloviti „Nadrikipari: Hrvatski narod nije od sadre!” i „Hrvati nisu kunići!: Stručan odgovor Wickhamu Steedu” ${ }^{103}$ Različiti je povijesni razvoj uzrokovao ne samo različito povijesno značenje nego i pripadnost različitim civilizacijama:

„To je čovjek [Robert W. Seton-Watson, op. T. K.], koji je mnogo skrivio i hrvatskom i srpskom narodu. Jer on je bio najgorljiviji zagovornik stvaranja Jugoslavije u inozemstvu. Njemu su hrvatski i srpski narod kunići, s kojima on pravi svoje učenjačke eksperimente. Zabio si je u glavu, da se baš na ponoru Istoka i Zapada, na granici Europe i Balkana, katoličanstva i pravoslavlja, Tomislavove države i Dušanova carstva dade stvoriti ideal od države. I od toga on ne popušta. Zaludu se koprcaju kunići. On ih hoće rezati i od dva kunića načiniti jedinstveni živi monstrum. I taj čovjek doista ne popušta u svojem 'znanstvenom' ludilu."'104

Hrvati su tako pripadnici „velikog Zapada” (Šufflayev izraz) i to su bili u cijeloj svojoj povijesti od Zvonimira preko Pavla Šubića do danas. Srbi su pak klasičan istočnjački narod, a hrvatski se narod tijekom povijesti borio s Istokom kao zapadni „bedem”. Šufflay će napisati da sve dok „bude ijedne hr-

\footnotetext{
$99 \quad$ Isto, 291-292.

100 Isto, 292.

101 ŠUFFLAY, „Dubine narodne svijesti”, Hrvatska misao, 24. 4. 1924., u: IPS, 69.

102 ŠUFFLAY, „San i java”, Pantheon I (1929), br. 5, u: IPS, 291.

103 ŠUFFLAY, „Nadrikipari”, Hrvatsko pravo, 24. 1. 1925., u: IPS, 196-198; ŠUFFLAY, „Hrvati nisu kunići!”, Hrvatsko pravo, 20. 9. 1928., u: IPS, 236-238.

104 ŠUFFLAY, „Nadrikipari”, Hrvatsko pravo, 24. 1. 1925., u: IPS, 196.
} 
vatske žare, iz nje će sukljati hrvatska historija, vjera otaca, zapadna kultura. Iz nje će sukljati sveta vatra. I o njenom svjetlu vidjet će Europa, da je malom narodu, koji je kroz tisuću godina stajao na braniku zapadne civilizacije, počinjena strašna nepravda” ${ }^{105}$ Prema Schöpflinovoj taksonomiji, riječ je o mitu o „nepravednom tretmanu”, koji je čest kod nacija koje se smatraju „predziđem kršćanstva”. Budući da je nacija „propatila” u prošlosti za dobro šire zajednice (Zapada), sada zaslužuje bolji tretman jer joj je "Zapad” dužan, proizlazi iz takvih mitova. ${ }^{106}$ Šufflay pridaje Zapadu, čije je temeljno obilježje katoličanstvo, samo pozitivne odrednice, što je specifikum Šufflayeva stvaralaštva u odnosu na druge međuratne hrvatske intelektualce. Seljački je pokret u dihotomiji Zapad - Istok Zapadu pridavao negativne vrijednosti, a slavenskom istoku pozitivne. ${ }^{107}$ Čak ni istaknuti hrvatski nacionalist Filip Lukas nije tvrdio da su Hrvati isključivo zapadni narod, nego da su „sinteza i most dvaju svjetova” ${ }^{108}$ Šufflay tvrdi da je na granici između Srba i Hrvata „puklo na dvoje Rimsko Carstvo”. Stoga je granica između Hrvata i Srba tisućljetni „ponor dvaju svjetova” ${ }^{109}$ Granica tih dvaju svjetova granica je između Bizanta i Rima, odnosno istočne i zapadne civilizacije. ${ }^{110}$ Hrvatstvo i „srpstvo” potpuna su suprotnost, a granica između njih granica je između „Istoka i Zapada, katoličanstva i pravoslavlja, kulture i barbarstva”. Zato hrvatstvo nije samo patriotizam, nego „hrvatska krv” na ovom prostoru predstavlja civilizaciju. „Hrvatstvo je tu sinonim za sve, što je lijepo i dobro stvorio evropski zapad.” Hrvati dakle imaju povijesnu misiju obrane Zapada. ${ }^{111}$ Takvo rezoniranje primjer je onoga što Schöpflin naziva mitom o „izabranosti i civilizirajućoj misiji”. Takvi mitovi „legitimiraju pretpostavku o moralnoj i kulturnoj superiornosti naspram svih suparnika i rivala te zahtijevaju priznanje jedinstvene moralne vrijednosti" ${ }^{112}$ Šufflay je na svojem suđenju u lipnju/srpnju 1921. definirao rijeku Drinu kao granicu koja je spomenuti „ponor između dvaju svjetova”. On je otac mita o granici na Drini, iako granica podijeljenoga Rimskog Carstva nije bila na Drini. ${ }^{113} \mathrm{Na}$ suđenju za povezanost s Hrvatskim komitetom Šufflay je govorio o Drini „na kojoj je puklo silno rimsko carstvo u dva dijela [...] koja je bila

\footnotetext{
ŠUFFLAY, „Obznana”, Hrvatsko pravo, 2. 7. 1925., u: IPS, 182.

SCHÖPFLIN, „The Functions of Myth”, 30-31.

ARALICA, Kmet, fiškal, hajduk, 415.

Isto, 433.

ŠUFFLAY, „Hrvati nisu kunići!”, Hrvatsko pravo, 20. 9. 1928., u: IPS, 236.

Isto, 237.

Isto. O tome što su „povijesne misije” Hrvata za različite mislioce i ideologe od sredine XVI. do početka ovoga stoljeća vidi: ŽANIĆ, „Simbolični identitet Hrvatske”, 161-202.

112 SCHÖPFLIN, „The Functions of Myth”, 31.

113 GOLDSTEIN, „Granica na Drini - značenje i razvoj mitologema”, 109-110.
} 
granica duhovna i kulturna". ${ }^{14}$ Stvaranjem mita o granici na Drini Šufflay ispunjava jednu od temeljnih funkcija mita. Schöpflin smatra da je mit način definiranja sebe. Mit pripisuje grupi određene osobine, koje imaju pozitivnu konotaciju, te „proširuje distinktivnost i stvara granicu”. ${ }^{115}$ Tako je stvorena granica prema Srbima, Jugoslaviji, Balkanu i mrskom Istoku. Katolička je vjera jedna od temeljnih značajki hrvatske nacije, i to je bila tijekom čitave povijesti, smatrao je Šufflay. Pravaš Milan Šufflay govorio je o Hrvatima kao predziđu kršćanstva, što je kontradiktorno s tradicionalnom pravaškom islamofilijom i uključivanjem muslimana u hrvatski nacionalni korpus. Upravo je Starčević govorio protiv tada diseminiranoga mita o „predziđu kršćanstva” u kontekstu čega se slavila Sigetska bitka i „hrvatski Leonida” Nikola Šubić Zrinski. Starčević je govorio da su Hrvati narod „koj je iztoku i zapadu prkosio”, a da Zrinski nije Leonida zato što „Leonida pade, braneć svoju domovinu, a taj Zrinski pogibe, braneć nepriatelje svoje domovine!”. ${ }^{116}$ Šufflay predstavlja odmak od pravaške tradicije, u kojoj religija nije bila čimbenik za određivanje nacionalne pripadnosti. Njegovo poimanje nacije, za razliku od Starčevićeva, nije liberalno, građansko. Starčevićev „Drugi” i Šufflayev „Drugi” nisu bili isti. „Vjera, sižući preko sloja krvnih veza u najdublju podsvijest svakog pojedinca, bitni je atribut narodne duše”, reći će Šufflay. Kod Hrvata je pak katolička vjera „srasla izvanredno čvrsto s narodnom dušom”. ${ }^{117}$ Hrvati su čitavu svoju povijest bili predziđe Zapada i brana prodoru Istoka. Zato nije slučajno da se Zvonimirovo ime „od svih hrvatskih narodnih kraljeva najjače usjeklo u narodno pamćenje”. ${ }^{118}$ Šufflay tvrdi da je „uspomena” na Zvonimira u hrvatskom puku bila „vanredno živa” u XIV. stoljeću. ${ }^{119}$ Naime, Zvonimir je bio papin vazal u vrijeme kada su papa i Normani ratovali protiv Bizanta, odnosno protiv Istoka. ${ }^{120}$ Zvonimir je bio eksponent katoličkoga Zapada, čiji je vođa papa, te je u Zvonimirovo doba „izvedena afirmacija zapadnjačke pripadnosti hrvatskoga naroda ostala dominantnom kroz sva poznija vremena". ${ }^{121}$ Šufflay se tu također razlikuje od dijela pravaške tradicije koji ističe ideal potpune hrvatske samostalnosti i neovisnosti, pri čemu ne postoji dihotomija Istok - Zapad jer je strana sila samo strana sila, bez drugih vrijednosnih konotacija, a Šufflay

\footnotetext{
114 Isto, 114. Šufflay je bio prvooptuženi, a među petnaest optuženika bio je i Ivo Pilar. Šufflay je optužen da je organizirao oslobađanje Aglaje Frank, supruge predsjednika emigrantskoga Hrvatskoga komiteta Ivana Franka. Vidi cijelu optužnicu: HR-HDA-832-MF, kut. 2, „Optužnica protiv Milana Šufflaya i ostalih", 3. 5. 1921.

115 SCHÖPFLIN, „The Functions of Myth”, 22.

116 ŽANIĆ, „Simbolični identitet Hrvatske”, 175.

117 ŠUFFLAY, „Katolička crkva i Hrvati”, Hrvatsko pravo, 10. 8. 1929., u: IPS, 275-276.

118 Isto, 276.

119 ŠUFFLAY, „Južna Italija i istočni Jadran u davnini”, Hrvatsko pravo, 7. 9. 1929., u: IPS, 274.

120 ŠUFFLAY, „Katolička crkva i Hrvati”, Hrvatsko pravo, 10. 8. 1929., u: IPS, 276-277.

121 ŠUFFLAY, „Hrvati u sredovječnom svjetskom viru”, u: IPS, 325.
} 
očito pravi razliku. Primjerice, pravaš Eugen Kumičić u romanu Kraljica Lepa iz 1902. prikazuje Zvonimira kojim manipulira žena Mađarica. Zvonimir je „rimski rob” koji je prisegnuo stranoj sili - papi, te ispunjava naredbe svojega gospodara, a ne zapovijedi svojega naroda i svoje države. Kumičić piše da je Zvonimir ubijen zato što je Hrvatima „sveta dužnost braniti svoju otadžbinu, a ne da osvajaju tuđe zemlje". ${ }^{122}$ Kulture i civilizacije su dakle na određeni način petrificirane kategorije otporne na vrijeme. Novi su hrvatski eksponent Zapada, nakon kralja Zvonimira, knezovi Šubići, uz čiju pomoć Anžuvinci dolaze na ugarsko prijestolje. Tada, riječima Milana Šufflaya, Hrvatska „postaje čvor" u srednjovjekovnom sukobu Istoka i Zapada koji predvodi papa. ${ }^{123}$ Nasuprot Hrvatima, eksponent Istoka su, naravno, Srbi. Tako je papa odobrio savez „tarentinskog prinčipa Filipa”, ugarskoga kralja Karla I. Anžuvinca i Mladena II. Šubića protiv srpskoga kralja Uroša II. Milutina, koji je „pravi skizmatik i neprijatelj kršćanske vjere”. ${ }^{124} \mathrm{U}$ tom je razdoblju cijela istočna obala Jadrana bila „operaciona baza papinstva protiv Istoka”. ${ }^{125}$ Nakon toga su Hrvati, naravno, bili „na bedemu Zapada protiv turske najezde” te su za papu i katolički svijet bili „predziđe kršćanstva”, a zemlja je bila „regnum Croatiae Catholicissimum”. ${ }^{126}$ Hrvatska nacija ima graničarski karakter, a Hrvati su „avant- ili arriere- gardi bijelog Zapada”. ${ }^{127}$ Mišljenje Šufflaya i nekih drugih intelektualaca o posebnosti Hrvata kao „granične” nacije koja brani Zapad nije specifično. Schöpflin to naziva mitom o „iskupljenju i patnji”. Naciji se pridaju iznimne moralne osobine i ističe se patnja koju je podnijela za više ciljeve („za Zapad”) tijekom povijesti. Spomenuti autor to objašnjava političkom i kulturnom marginalizacijom (periferni položaj) zemalja u srednjoj i (jugo) istočnoj Europi koje imaju takve mitove. Te su zemlje bile „predziđe kršćanstva” i omogućile razvoj ostatku Zapada, ali su one umalo propale, poručuju takvi mitovi. ${ }^{128}$ Zbog "graničarske značajke” hrvatskoga nacionalizma on je iznimno poželjan jer je u povijesti, a i u Šufflayevo vrijeme, branio Zapad od raznih nasrtaja.

„Kad se ta historijska značajka [graničarski karakter hrvatske nacije, op. T. K.] posve jasno uoči, svaki hrvatski inteligenat, pa čak i filozof, znat će posve točno da je hrvatski nacionalizam nešto daleko više od nacionalizma bilo ko-

122 ŽANIĆ, „The Curse of King Zvonimir”, 96.

123 ŠUFFLAY, „Hrvati u sredovječnom svjetskom viru”, u: IPS, 329.

124 Isto, 330.

125 ŠUFFLAY, „Katolička crkva i Hrvati”, Hrvatsko pravo, 10. 8. 1929., u: IPS, 278.

126 Isto, 277.

127 ŠUFFLAY, „Esej o Vjekoslavu Klaiću”, Hrvatsko pravo, 4. 8. 1928., u: IPS, 84.

128 SCHÖPFLIN, „The Functions of Myth”, 29-30. Ista je misao prisutna i kod dijela španjolskih intelektualaca. Vidi razgovor Salvadora de Madariage s Bogdanom Radicom u: RADICA, Agonija Europe, 187-193. 
jeg ne-pograničnog naroda, da je viši i čovječanstvu korisniji od integralnog jugoslavenstva. Filozof s pravom može držati, da je nacionalna ideja negativna, jer raskida čovječanstvo i koči napredak raznih internacionala, pravi tuđine, a tuđin i neprijatelj su sinonimi. Ali dok postoji drevni jaz između sredozemnog Istoka i Zapada i puca još daleko veći, svjetski jaz između Azije i Evrope, dok s Balkana kroz 500-godišnju bizantinsko-tursku retortu juri XIV. vijek, hrvatski nacionalizam označuje jedan od najsnažnijih bedema zapadne civilizacije. Dok je ova ugrožena, a danas jeste, hrvatski nacionalizam ne znači samo ljubav prema rodnoj grudi i hrvatskim domovima na njoj, on ne znači lokalni patriotizam, već lojalnu službu čitavom bijelom Zapadu. I zato je on apsolutno pozitivan." 129

Usprkos osmanskim osvajanjima, „ostatak ostataka” Hrvatske sačuvao je „jezgru (nukleus) hrvatske zapadnjačke nacije”. ${ }^{130}$ Taj dio Hrvatske, koji nikad nije prošao „kroz bizantinsko-tursku državnu retortu”, može „regenerirati” ostale hrvatske krajeve, odnosno „sve dijelove hrvatske plazme”. ${ }^{131}$ Dakle, upravo je dio Hrvatske koji nije „orijentaliziran” i „kontaminiran” Istokom centar koji mora provesti obnovu zato što se radi o čisto zapadnjačkom dijelu Hrvatske. Za razliku od nekih hrvatskih nacionalista, Šufflay ne pridaje dinarskoj rasi središnju važnost i „najbolje” osobine unutar hrvatskoga nacionalnoga korpusa. ${ }^{132}$ Štoviše, implicitno se vidi da vrijednosno najbolje osobine daje upravo onim Hrvatima na koje je utjecala „altajska ili turanska natruha”. Ta je elita dala „slavenskoj baštinskoj masi Hrvata zasebnu tvrdokornost i gospodsku rigidnost”. Zato „najtvrđe, neslomljive karaktere još i danas u Hrvata stvaraju Zagorje i Lika”. ${ }^{133}$

Kako ističe Keith Jenkins, povijest služi za legitimiranje sadašnjosti i budućnosti, odnosno „na temelju prošlosti nastaju objašnjenja za sadašnje postojanje i buduće programe”. ${ }^{134}$ Edward Said reći će da je pozivanje na prošlost jedna od „najčešćih strategija interpretacije sadašnjosti” ${ }^{135}$ Slično tvrdi i Anthony Smith, koji kaže da je potrebno „ponovno otkriti” „vrijednu i distinktiv-

\footnotetext{
129 ŠUfFLAY, „Esej o Vjekoslavu Klaiću”, Hrvatsko pravo, 4. 8. 1928., u: IPS, 84. U neobjavljenom članku napisanom na engleskom, vjerojatno 1928., naslovljenom „Characteristic Marks of the Croatian Nation”, Šufflay iznosi istu ideju, ali govori i o liniji koju je stvorila „bizantinsko-turska retorta”, a koja dijeli „istočni od zapadnog mentaliteta”, odnosno „Aziju od Europe” [kurziv dodao T. K.]. HR-HDA-832-MF, kut. 2, „Characteristic Marks of the Croatian Nation”, nije datirano, str. 2-3.

130 ŠUFFLAY, „Esej o Vjekoslavu Klaiću”, Hrvatsko pravo, 4. 8. 1928., 83.

131 Isto.

132 O promišljanju o „dinarskoj rasi” u međuratnom razdoblju i u Nezavisnoj Državi Hrvatskoj vidi: BARTULIN, The Racial Idea, 50-52, 94-103, 169-181.

133 ŠUFFLAY, „Esej o Vjekoslavu Klaiću”, Hrvatsko pravo, 4. 8. 1928., u: IPS, 80-81.

134 JENKINS, Promišljanje historije, 36.

135 SAID, Culture and Imperialism, 3.
} 
nu prošlost” da bi nacija mogla imati aspiraciju prema „slavnoj sudbini”. ${ }^{136}$ Šufflay je „zlatno doba” hrvatske nacije pronašao u vjekovnom boju Hrvata, kao predstavnika Zapada, s Istokom. Mitovi o zlatnom dobu služe kao putokaz za politiku u sadašnjosti, a slavna prošlost treba biti preslikana u sadašnjost i budućnost. U Šufflayevu su „zlatnom dobu” Hrvati bili na pravom putu - bili su branik Zapada. ${ }^{137}$ Povijesni narativ o historijskom okcidentalizmu hrvatske nacije služi i za opravdanje i pružanje temelja za politiku koju zastupa Šufflay - približavanje Hrvata „Velikom Zapadu” u predstojećem sukobu Istoka i Zapada.

\section{Geopolitika Milana Šufflaya}

Termin geopolitika skovao je 1899. Rudolf Kjellén, ali upotreba toga pojma nipošto nije jednoznačna. ${ }^{138} \mathrm{U}$ ovom se radu pod geopolitikom podrazumijeva „politički izraz geografskoga determinizma s poimanjem da tlo na kojem živi neki narod ima odlučujući utjecaj na oblike njegova društvenog ustrojstva”. ${ }^{139}$ Slično je geopolitiku definirao i Milan Šufflay. Za njega je geopolitika „nauka o utjecajima, što ih vrši kora zemaljska na državne tvorbe i njihove granice” ${ }^{140}$ Već je istaknuto da je Šufflay argumentirao da je Jugoslavija neprirodna i neodrživa tvorevina s geografskoga stajališta, a geografski su faktori za njega bili bitni pri oblikovanju nacije. Geografsko deterministička gledišta bila su raširena u međuratnom razdoblju, a tada su djelovali neki od najpoznatijih geopolitičara poput Halforda Mackindera i Karla Haushofera. ${ }^{141}$ Geografski determinizam podrazumijeva da prošla, sadašnja i buduća društva ovise $\mathrm{o}, \mathrm{tj}$. determinirana su objektivnim geografskim uvjetima. ${ }^{142}$ Šufflay se neće pozivati na te autore, ali se svakako može reći da je promišljao o geopolitici i bio prostorni/geografski determinist, a anticipirat će i tezu o „sukobu civilizacija” Samuela P. Huntingtona.

U jednom će članku kritizirati Radića, koji je hvalio britanski državni ustroj, odnosno britansku monarhiju. Šufflay smatra da je upravo geografija (činjenica da je Velika Britanija otok) uvjetovala društveni ustroj Velike Britanije, koji se ne može drugdje "preslikati”. Britanska monarhija nije „pala sa Mjeseca”, nego su „trebale stotine godina, da se razvije na jednom od ne-

136 SMITH, „The 'Golden Age' and National Renewal”, 36.

137 Isto, 36-59.

138 AGNEW, Geopolitics, 5.

139 „Geopolitika”.

140 ŠUFFLAY, „Geopolitičke sile”, Hrvatsko pravo, 20. 10. 1924., u: IPS, 172.

${ }_{141}$ O geopolitici krajem XIX. stoljeća i u međuraću vidi: HEFFERNAN, „Fin de siècle, fin du monde?”, 27-51. O njemačkoj geopolitici vidi: NATTER, „Geopolitics in Germany”, 187-203.

142 BASSIN, „Politics from Nature”, 29. 
prijatelja dobro zaštićenom otoku. Ta monarhija stvorena je historijom, a ne zaključkom jedne parlamentarne većine ili manjine a la Davidović-Trumbić", napisat će Šufflay. Kritika Radića, koji ne razumije da su institucije organski povezane s geografijom, odnosno tlom, povezana je i sa Šufflayevim stajalištima o naciji. Ako je nacija primordijalna i vječna, logičan je nastavak da ima i „drevni” teritorij koji utječe na njezine karakteristike. Spengler je također govorio o „dubokim sponama s tlom” koje ne postoje u kozmopolitskim velegradovima. ${ }^{143}$

Šufflay će u svojoj kritici versajskoga poretka koristiti upravo geopolitičke argumente. Smatrao je da pri krojenju novih granica u Versaillesu nisu uzete $\mathrm{u}$ obzir „geopolitičke sile”. Zbog toga su nastradale „velike ekonomske jedinice, kojih je harmoničko funkcioniranje sredila kora zemaljska kroz stoljeća”. Primjerice, zato je srednja Europa u kaosu. Šufflay zaključuje da versajski poredak ne uništavaju samo neriješena nacionalna pitanja, „već u prvom redu geopolitičke sile”. ${ }^{144}$ Jedan od utemeljitelja geopolitike, Halford Mackinder, uzimao je u obzir i rasne kategorije. Biološko nasljeđe, odnosno rasna pripadnost, za njega je važan element geopolitičke stvarnosti. Prema Mackinderu, rase se, dugoročno, prilagođavaju na svoje prirodno okruženje. Različita pak prirodna okruženja uvjetuju različit mentalitet ljudi. Tako britansko podneblje „proizvodi” ljude sklone slobodi i civilizaciji, a ruske stepe, misli Mackinder, stvaraju čovjeka koji prihvaća despotsku vlast. Ističući inferiornost neeuropskih naroda, Mackinder je opravdavao britanski imperijalizam i „civilizirajuću misiju”. ${ }^{145}$ Pogotovo je velik utjecaj imao jedan od utemeljitelja geopolitike i utemeljitelj političke geografije Friedrich Ratzel, čiji su učenici, kao i on, bili geografski deterministi. Smatrali su da je okolina glavni čimbenik za razvoj kulture i mentaliteta određenoga naroda. Pritom su ratzelijanci, kako ističe Aralica, bili konkurencija dominantnoj rasnoj teoriji. Aralica kaže da je teško povući oštru granicu između rasnih teoretičara i ratzelijanaca jer se često te dvije struje preklapaju, što je po njegovu mišljenju vidljivo u djelu Jovana Cvijića. ${ }^{146}$ Šufflay će ponajviše raspravljati o dinarskoj rasi, što je povezano i s njegovim znanstvenim interesom za Albaniju. Geografija je ono što, primarno, uvjetuje način života i „osobine”, a ne rasna pripadnost, iako su geografija i rasa često izrazito povezane. „Zeta i sjeverna Albanija tvore jedan jedini biološki facies; nerazdruživo povezane su one jednakom plastikom tla, istom ilirskom krvlju, istim historijskim bolima", napisat će Šufflay. ${ }^{147}$ Geografija toga prostora uvjetuje stočarstvo kao temeljnu

\footnotetext{
143 KAPLAN, Osveta geografije, 57-58.

144 ŠUFFLAY, „Geopolitičke sile”, Hrvatsko pravo, 20. 10. 1924., u: IPS, 172.

145 KEARNS, „Imperial Geopolitics”, 175-176.

146 ARALICA, Kmet, fiškal, hajduk, 343.

147 ŠUFFLAY, „Nacijonalne maglice”, Obzor LXV (1924), br. 49, u: IPS, 131.
} 
granu gospodarstva i kao način života. Šufflayevim riječima, „marvogojstvo” je „nametnuto plastikom tla”. Neovisno o etničkom podrijetlu stanovništva, ljudi dinarskoga područja imaju istu društvenu strukturu i žive na isti način. ${ }^{148}$ Šufflay kaže da su Samuel Adams i Benjamin Franklin, iako engleskoga etničkog podrijetla, Amerikanci, a ne Englezi, zato što su „plod onoga drveta, koje je poraslo od engleskog sjemena usađenog na novo tlo”. ${ }^{149}$ Dakle, novo je „tlo” odredilo i novu nacionalnu pripadnost.

Samuel P. Huntington objavio je 1993. članak „Sukob civilizacija”, koji je potom proširen i 1996. objavljen kao knjiga Sukob civilizacija i preustroj svjetskog poretka. Huntington je argumentirao da će se budući sukobi i savezništva u svijetu stvarati po civilizacijskim linijama. Detektirao je sljedeće civilizacije: zapadna, konfucijanska, japanska, islamska, hinduistička, slavensko-pravoslavna, latinskoamerička i možda jedna afrička. ${ }^{150}$ Temeljna je Huntingtonova teza da „kultura i kulturni identiteti, koji su u svom najuopćenijem obliku civilizacijski identiteti, uobličuju uzorke kohezije, raspada i sukoba u svijetu poslije hladnog rata". ${ }^{151}$ Šufflay također međunarodne odnose promatra kroz civilizacijsku vizuru. Kao što je istaknuto, povijest Hrvata na neki je način predstavio kao civilizacijsku borbu za zapadnu civilizaciju. U vrijeme svojega života on „iščekuje” apokaliptički sukob Istoka i Zapada:

„Obračun između zapadne, industrijsko-kapitalističke Evrope i sovjetske Rusije još nije izvršen. Još nije započela prava bitka na život i smrt između bijelog intelekta Zapada, kojemu je najodličniji predstavnik anglosaska rasa i intuicije Istoka, kojemu je evropska predstraža Rusija. Sve to što je bilo, tek su gigantske pripreme za odsudan boj između dva svijeta, između Anglo-amerikanca i Euroazijata." 152

Taj je sukob „strahovit” i bit će obilježje cijeloga XX. stoljeća te predstavlja borbu za spas zapadne civilizacije, isticao je Šufflay. „On će jenjati i bujati, ali prestati ne će do konačnog sloma. Na kocki je sudbina čitave bijele rase. A ta rasa imade danas još, i za nekoliko generacija, strašnu energiju." ${ }^{153}$ Ipak, Azija se diže iz „tisućljetnog polu sna” i prijetnja je zapadnoj dominaciji. ${ }^{154}$ Rusija

\footnotetext{
148 Isto.

149 ŠUFFLAY, „Building the American Nation”, Jutarnji list (Zagreb), 4. 1. 1923., u: IPS, 65. Na drugome mjestu opet govori o „violentnom dinarskom tipu” i objašnjava da je on prisutan kod Arbanasa, južnih Srba i južnih Hrvata. ŠUFFLAY, „Hrvatska krv i zemlja”, Starohrvatska prosvjeta I (1927), u: IPS, 74-75.

150 HUNTINGTON, Sukob civilizacija.

151 Isto, 36.

152 ŠUFFLAY, „Svjetske tajne sile”, Hrvatsko pravo, 23. 9. 1924., u: IPS, 166.

153 ŠUFFLAY, „Uoči izbora”, Hrvatsko pravo, 6. 2. 1925., u: IPS, 204.

154 ŠUFFLAY, „Pacifik i naši pacifiste od Pekinga do Zagreba”, Hrvatsko pravo, 3. 1. 1925., u: IPS, 184.
} 
(Sovjetski Savez) europska je „predstraža” Istoka. Nju će Šufflay nazvati „euroazijskim dvoživcem”. Rusija je duhovno bliža Istoku te se „stavlja u izravan duševan dodir s najvećim ljudskim rezervoarima čitavog svijeta, s Kitajem [Kinom, op. T. K.] i Indijom”. ${ }^{155}$ Euroazijska Rusija, Kina i Indija, drži Šufflay, „ugrožavaju smrtno” Sjedinjene Američke Države i Veliku Britaniju. Pritom je Rusija „najopasnija” zato što „ima bijela sredstva, a žutu dušu. Ona je jedina bijela velevlast, koja duboko shvaća Aziju i može njom upravljati”. Rusija je dakle ovladala zapadnom tehnologijom, ali ima istočnjačku „dušu”. ${ }^{156}$ Zbog istočne prijetnje zapadne države popuštaju Njemačkoj (Dawesov plan) da bi ju pridobile na svoju stranu, tj. da se ona ne bi pridružila istočnjačkom bloku. ${ }^{157} \mathrm{Za}$ predstojeći civilizacijski sukob ključna su dva područja: Balkan i Tihi ocean. Na Balkanu su, kaže Šufflay, upravo Bugarska i Hrvatska ključne točke. ${ }^{158}$ Balkan je, pa tako i Hrvatska, „poprište gigantske borbe između azijskog Istoka i anglo-američkog Zapada, između Rusije i Amerike”, pisao je Šufflay. ${ }^{159}$ Prema njegovu mišljenju, sukob između „anglo-američkog bloka i euroazijske lige” bit će „značajka čitavog 20. stoljeća”. U tom kolosalnom sukobu „predstavnici staroga evropskog društvenog poretka” jesu „naravni saveznici”, tj. „klijenti velikoga konzervativnog anglo-američkog bloka”. ${ }^{160}$ Šufflay ne dvoji: Hrvati u tom „dizanju korduna proti Sovjetima” moraju biti, kao i uvijek u povijesti, na strani Zapada. Zato će Šufflay kritizirati Stjepana Radića i njegov odlazak u Moskvu jer „hrvatski narod u srcu Europe, iza korduna proti Sovjetima ne može i ne smije biti ekspozitura Istoka, ne će li da bude dobrovoljna i suvišna žrtva za daleku budućnost. [...] Tihi ocean stvorio je frontu proti Sovjetima. On od balkanskog, orientalnog Biograda [Beograda, op. T. K.] stvara sredstvo Velikog Zapada. A tisućljetnoj zapadnoj hrvatskoj naciji donosi progone. Sve zato, jer je vodstvo HRSS-a prekinulo s historičkim tradicijama i jer naši pacifisti nisu poznavali dinamike Pacifika". ${ }^{161}$

\footnotetext{
155 ŠUFFLAY, „Svjetske tajne sile”, Hrvatsko pravo, 23. 9. 1924., u: IPS, 166. U Manifestu Hrvata radikala iz 1925. kaže da je Sovjetski Savez „zakleti neprijatelj staroga društvenog poretka, zapravo bijela predstraža Azije i žutoga mentaliteta”. HR-HDA-832-MF, kut. 2, „Manifest Hrvata radikala”, nije datirano, str. 1.

156 ŠUFFLAY, „Svjetske tajne sile”, Hrvatsko pravo, 23. 9. 1924., u: IPS, 167.

157 ŠUFFLAY, „Umgruppierung”, Hrvatsko pravo, 30. 9. 1924., u: IPS, 170.

158 ŠUFFLAY, „Svjetske tajne sile”, Hrvatsko pravo, 23. 9. 1924., u: IPS, 168. Ipak, Tihi ocean najvažnija je točka u sukobu Istoka i Zapada. Prema Šufflayu, ondje je „započela strašna borba” o kojoj ovisi „sudbina čovječanstva”. Isto, 163-164.

159 ŠUFFLAY, „Umgruppierung”, Hrvatsko pravo, 30. 9. 1924., u: IPS, 169. Za Šufflaya su događaji na drugom kraju svijeta važni za Hrvatsku. On promatra svijet i međunarodne odnose u njemu kao strukturiranu cjelinu, što je jedno od obilježja geopolitičkoga razmišljanja. AGNEW, Geopolitics, 31-32.

160 HR-HDA-832-MF, kut. 2, „Manifest Hrvata radikala”, nije datirano, str. 1.

161 ŠUFFLAY, „Pacifik i naši pacifiste od Pekinga do Zagreba”, Hrvatsko pravo, 3. 1. 1925., u: IPS, 184-185.
} 
Stjepan Radić počinio je dakle smrtni grijeh odlaskom u Moskvu. Zbog kratkovidnosti i ignorancije izdao je hrvatsku vjernost Zapadu u vrijeme „umgruppierunga” (pregrupiranja), odnosno konsolidacije zapadnih i istočnih snaga. Zato je istočnjački Beograd prihvatljiv Zapadu. Pred veljačke izbore 1925. Šufflay piše da Radićev pokušaj povezivanja sa Sovjetskim Savezom ne bi vrijedio i kad bi bio uspješan jer „dovodi čitavi hrvatski narod u unakrsnu vatru čitave Zapadne Europe i Biograda!”. To je katastrofalan ishod, a oni koji to ne vide „sastoje se od pilećeg mozga i ogromne torbe žuči”. ${ }^{162}$ Koliko je ocjena Radićeve stranke plod dubokoga „promišljanja”, a koliko praktične političke borbe, teško je prosuditi. No, uzimajući u obzir prijašnje panegirike Radiću kao vođi i praktično djelovanje Šufflaya kao političara u tom razdoblju, vjerojatno se radi o drugom. Šufflay je naime, kao član HSP-a, aktivno radio na osnivanju Hrvatske narodne radikalne stranke, koja bi ušla u savezništvo sa srpskim radikalima i tako zadala „smrtni” udarac jugoslavenskom unitarizmu. U Manifestu Hrvata radikala, napisanom vjerojatno ujesen 1925., Šufflay kaže da je Hrvatska republikanska seljačka stranka, u kontekstu apokaliptičnoga sukoba anglo-američkoga bloka i euroazijanstva, stranka s jakim crtama istočnjaštva i euroazijanstva, a Narodna radikalna stranka, kao konzervativna i monarhistička ${ }^{163}$, „izvrsno pristaje u svjetsku zapadnjačku struju anglo-američkog bloka”. Kao Radićev magnum crimen kojim je zadao nevolje hrvatskome narodu Šufflay spominje odlazak u Moskvu. ${ }^{164}$ Zbog te istočnjačke tendencije kod Radića pravaši bi trebali surađivati sa sebi sličnima kod Srba. Šufflay piše da će hrvatski radikali raditi na tome da Hrvati i dalje ostanu na braniku zapadne civilizacije, „a da to uzmognu što uspješnije provoditi oni stupaju u najtjesniju vezu s nacionalnim Srbima jednakog mentaliteta” ${ }^{165}$ Dvije konzervativne i nacionalističke opcije - pravaši i radikali - trebale su se, smatrao je Šufflay, zbog „interesa bijele rase i interesa Evrope” ujediniti „proti socijalnom radikalizmu i revolucionarstvu". 166

\footnotetext{
162 ŠUFFLAY, „Nova fronta”, Hrvatsko pravo, 10. 1. 1925., u: IPS, 190.

163 Šufflay navodi da je monarhija „kategorički imperativ i hrvatskih historičkih tradicija i hrvatske socijalne strukture” budući da su Hrvati seljački narod, a seljački je narod „monarhističan”. HR-HDA-832-MF, kut. 2, „Manifest Hrvata radikala”, nije datirano, str. 1-2.

164 HR-HDA-832-MF, kut. 2, „Manifest Hrvata radikala”, nije datirano; MATKOVIĆ, „Šufflayeva akcija za osnivanje Hrvatske narodne radikalne stranke”, 170-171.

165 HR-HDA-832-MF, kut. 2, „Manifest Hrvata radikala”, nije datirano, str. 3; MATKOVIĆ, „Šufflayeva akcija za osnivanje Hrvatske narodne radikalne stranke”, 171.

166 HR-HDA-832-MF, kut. 2, „Manifest Hrvata radikala”, nije datirano, str. 3. Za beogradsku Pravdu Šufflay će objasniti da se jugoslavenska ideja „pokazala kao dinamit koji razara i srpske i hrvatske narodne svetinje” te će zaključiti da se „vezuju konzervativne vlade, pa mogu i stranke”. „Izjava Šuflaja”, Pravda (Beograd), 21. 4. 1925., 3.
} 


\section{Zaključak}

U radu je dokazano da su Šufflayevi ideološki pogledi antimodernistički, odnosno da pripadaju antiprosvjetiteljskoj tradiciji, i uklopljeni su u šira europska intelektualna kretanja u međuraću. Šufflayev se antimodernizam ogleda u kritici moderne civilizacije i njezinih manifestacija. On je vitalist, „instinkt” stavlja ispred razuma, a pesimistični ton kritike sadašnjega stanja blizak je Spengleru, čiju je čuvenu knjigu Propast Zapada Šufflay prikazao. Šufflay kritizira modernu urbanu civilizaciju, glorificira selo, a zalaže se za „novo srednjovjekovlje” u kojem će duhovne vrijednosti ojačati te imati primat nad materijalnima. Tada će zavladati stari, „iskonski” organski poredak, u kojem je svaki pojedinac povezan sa zajednicom. Zajednica u Šufflayevoj viziji ima primat nad pojedincem, što se reflektira u Šufflayevu pogledu na naciju.

Njegov je nacionalizam organski, integralan, primordijalan, a ne liberalan poput Starčevićeva, iako dolazi iz pravaške tradicije. Šufflayev pogled na naciju, koja je kulturno/civilizacijski determinirana te je „organska” zajednica živih, mrtvih i budućih generacija sa „sviješću” i „dušom” (postoji od iskona), sličan je Barrèsovu, Maurrasovu i Lukasovu pogledu. Šfflay gradi hrvatski nacionalni identitet suprotstavljen jugoslavenskoj ideji, naglašavajući pritom nepremostive razlike između Hrvata i Srba koje, smatrao je, čine jugoslavenstvo i Jugoslaviju neodrživima. On marginalizira važnost jezika, a kao faktore ključne za naciju i nacionalni identitet ističe geografske, rasne, kulturne i povijesne razloge, odnosno povijesno pamćenje. Kao rodonačelnik mita o Drini kao granici između dvaju svjetova - civiliziranoga Zapada i barbarskoga Istoka, on konstruira hrvatski nacionalni identitet kao isključivo zapadnjački, zbog čega ističe katoličku vjersku pripadnost Hrvata, što je također otklon od pravaške tradicije iako je bio istaknuti član HSP-a u prvoj Jugoslaviji. Zbog svih navedenih čimbenika koji tvore naciju i zato što je Jugoslavija mehanička, antiorganska tvorevina, ona je neprirodna i štetna za Hrvate, smatrao je Šufflay.

Šufflay je smatrao da postoje dva esencijalistička homogena bloka (Istok i Zapad), koja se nalaze u stanju vječnoga sukoba. Taj sukob, smatrao je, obilježje je i njegova doba, a bit će značajka cijeloga XX. stoljeća. U tom sukobu Hrvatska mora, kao što je u povijesti uvijek bila, biti bedem Zapada i brana protiv Istoka, kao što je to bio Zvonimir, kao što su to bili Šubići te kao što su Hrvati bili Antemurale Christianitatis. Zato kritizira Radićevo koketiranje sa Sovjetima te se čak u jednom periodu zalaže za osnivanje Hrvatske radikalne stranke, koja bi bila u savezu sa srpskim radikalima. Iako nije pisao znanstvene rasprave iz političke geografije i geopolitike, Šufflay promišlja o geopolitičkim pitanjima te je za njega „plastika tla”, odnosno geografija, determinirajući čimbenik za društveno ustrojstvo i naciju kao takvu. 


\section{Arhivski izvori}

HR-HDA-832-MF: Hrvatska, Hrvatski državni arhiv, Zagreb, fond 832, Osobni arhivski fond Milan Šufflay.

\section{Tisak}

Pravda (Beograd), 1925.

\section{Objavljeni izvori}

JELČIĆ, Dubravko, ur. Milan Šufflay. Izabrani politički spisi. Zagreb: Matica hrvatska, 2000.

\section{Literatura}

AGNEW, John. Geopolitics: Re-visioning World Politics. London; New York: Routledge, ${ }^{2} 2004$.

ARALICA, Višeslav. Kmet, fiškal, hajduk. Konstrukcija identiteta Hrvata 1935. - 1945. Zagreb: Naklada Ljevak, 2016.

BANAC, Ivo. „Zarathustra in Red Croatia: Milan Šufflay and his Theory of Nationhood". U: National Character and National Ideology in Interwar Eastern Europe, ur. Ivo Banac i Katherine Verdery. New Haven: Yale Center for International and Area Studies, 1995, 181-193.

BARTULIN, Nevenko. „The Anti-Yugoslavist Narrative on Croatian Ethnolinguistic and Racial Identity, 1900-1941". East Central Europe 39 (2012), br. 2-3: 331-356.

BARTULIN, Nevenko. The Racial Idea in the Independent State of Croatia. Leiden; Boston: Brill, 2014.

BASSIN, Marc. „Politics from Nature: Environment, Ideology, and the Determinist Tradition". U: A Companion to Political Geography, ur. John Agnew, Katharyne Mitchell i Gerard Toal. Oxford: Blackwell Publishing, 2003, 13-29.

BERDJAJEV, Nikolaj. Novo srednjovjekovje. Razmišljanje o sudbini Rusije i Evrope. Prev. Nikola Thaller. Split: Laus, 1991.

BERGSON, Henri. Stvaralačka evolucija. Prev. Tomislav Medak. Zabok; Zaprešić: HAUZ; Igitur, 1999.

BROOKS TOMLJANOVICH, William. Biskup Josip Juraj Strossmayer. Nacionalizam i moderni katolicizam u Hrvatskoj. Zagreb: Dom i svijet, 2001.

BUCHOLTZ, Mary; HALL, Kira. „Identity and Interaction: A Sociocultural Linguistic Approach”. Discourse Studies 7 (2005), br. 4-5: 585-614. 
BURKE, Peter. What is Cultural History? Cambridge: Polity Press, 2004.

CARR, Edward Hallett. Što je povijest? Prev. Snježana Koren. Zagreb: Srednja Europa, 2004.

CREVELD, Martin van. The Rise and Decline of the State. Cambridge: Cambridge University Press, 1999.

FUKUYAMA, Francis. Kraj povijesti i posljednji čovjek. Prev. Rajka Rusan Polšek. Zagreb: Hrvatska sveučilišna naklada, 1994.

„Geopolitika”. U: Hrvatska enciklopedija (on-line). Leksikografski zavod „Miroslav Krleža”. Pristup ostvaren 17. 3. 2020. https://www.enciklopedija.hr/natuknica. aspx? ID $=21718$.

GOLDSTEIN, Ivo. „Granica na Drini - značenje i razvoj mitologema”. U: Historijski mitovi na Balkanu, ur. Husnija Kamberović. Sarajevo: Institut za istoriju, 2003, 109-139.

GRDEŠIĆ, Maša. „Oni nas vode na Balkan: Milan Šufflay u svjetlu antimodernizma”. 15 dana 47 (2004), br. 4-5: 18-27.

GROSS, Mirjana. Izvorno pravaštvo: ideologija, agitacija, pokret. Zagreb: Golden marketing, 2000.

GROSS, Mirjana. Suvremena historiografija: korijeni, postignuća, traganja. Zagreb: Novi Liber, 1996.

HEFFERNAN, Michael. „Fin de siècle, fin du monde? On the Origins of European Geopolitics, 1890-1920". U: Geopolitical Traditions: A Century of Geopolitical Thought, ur. Klaus Dodds i David Atkinson. London: Routledge, 2000, 27-51.

HORVAT, Josip. Hrvatski panoptikum. Zagreb: Stvarnost, 1965.

„Hugo de Vries”. U: Encyclopaedia Britannica (on-line). Pristup ostvaren 15. 3. 2020. https://www.britannica.com/biography/Hugo-de-Vries.

HUIZINGA, Johan. U sjeni sutrašnjice. O dijagnozi zla od kojega boluje naše vrijeme. Prev. Alexander Anton Maria Buczynski. Zagreb: Dom i svijet, 2006.

HUNTINGTON, Samuel P. „Conservatism as an Ideology”. The American Political Science Review 51 (1957), br. 2: 454-473.

HUNTINGTON, Samuel P. Sukob civilizacija i preustroj svjetskog poretka. Prev. Darko Brdarić, Mirko Kovač i Janko Paravić. Zagreb: Izvori, 1997.

IRVINE, Judith T.; GAL, Susan. „Language Ideology and Linguistic Differentiation”. U: Regimes of Language: Ideologies, Politics and Identities, ur. Paul V. Kroskrity. Santa Fe: School of American Research Press, 2000, 35-84.

JAREB, Mario. Ustaško-domobranski pokret: od nastanka do travnja 1941. godine. Zagreb: Školska knjiga; Hrvatski institut za povijest, 2006. 
JELČIĆ, Dubravko. „Predgovor”. U: Milan Šufflay. Izabrani politički spisi, ur. Dubravko Jelčić. Zagreb: Matica hrvatska, 2000, 11-26.

JENKINS, Keith. Promišljanje historije. Prev. Snježana Koren. Zagreb: Srednja Europa, 2008.

KAMUSELLA, Tomasz D. „Language as an Instrument of Nationalism in Central Europe". Nations and Nationalism 7 (2001), br. 2: 235-251.

KAPLAN, Robert. Osveta geografije. Što nam zemljovid svijeta otkriva o budućim sukobima i o borbi protiv sudbine. Prev. Žarko Vodinelić. Zagreb: Izvori, 2014.

KEARNS, Gerry. „Imperial Geopolitics: Geopolitical Visions at the Dawn of the American Century". U: A Companion to Political Geography, ur. John Agnew, Katharyne Mitchell i Gerard Toal. Oxford: Blackwell Publishing, 2003, 173-186.

KLJAIĆ, Stipe. Nikada više Jugoslavija. Intelektualci i hrvatsko nacionalno pitanje (1929. - 1945.). Zagreb: Hrvatski institut za povijest, 2017.

KRAVAR, Zoran. Antimodernizam. Zagreb: AGM, 2004.

KRAVAR, Zoran. „Revizionizam tvrdo ukoričen”. Zarez (2001), br. 58: 14-15.

KUVAČIĆ, Ivan. „O dometima jedne istraživačke strategije”. Revija za sociologiju 24 (1993), br. 3-4: 131-136.

LE BON, Gustave. Psihologija gomila. Prev. Ivan Lulić. Zagreb: Globus; Pravni fakultet Sveučilišta u Zagrebu, Centar za stručno usavršavanje i suradnju s udruženim radom, 1989.

MATKOVIĆ, Hrvoje. „Šufflayeva akcija za osnivanje Hrvatske narodne radikalne stranke". Časopis za suvremenu povijest 23 (1991), br. 1-3: 167-173.

MATOTA, Josip. Šuflayevo shvaćanje uloge povijesti u narodnoj svijesti Hrvata. Bjelovar: Matica hrvatska, Ogranak Bjelovar, 2006.

NATTER, Wolfgang. „Geopolitics in Germany, 1919-45: Karl Haushofer and the Zeitschrift für Geopolitik”. U: A Companion to Political Geography, ur. John Agnew, Katharyne Mitchell i Gerard Toal. Oxford: Blackwell Publishing, 2003, 187-203.

NOLTE, Ernst. Fašizam u svojoj epohi. Prev. Mirjana Popović i Zlatko Krasni. Beograd: Prosveta, 1990.

OGBURN, William F. „Cultural Lag as Theory”. Sociology \& Social Research 41 (1957), br. 3: 167-174.

OTIS, Laura. Organic Memory: History and the Body in the Late Nineteenth and Early Twentieth Centuries. Lincoln: University of Nebraska Press, 1994.

OVERING, Joanna. „The Role of Myth: An Anthropological Perspective, or: 'The Reality of the Really Made-Up'”. U: Myths and Nationhood, ur. Geoffrey A. Hosking i George Schöpflin. New York: Routledge, 1997, 1-18.

PARETO, Vilfredo. Uspon i pad elita. Primjena teoretske sociologije. Prev. Dragutin Hlad. Zagreb: Feniks knjiga, 2011.

PAYNE, Stanley G. A History of Fascism, 1914-1945. London: University College London Press, 1995. 
RAČKI, Franjo. „Jugoslovjenstvo”. U: Josip J. Strossmayer, Franjo Rački, Politički spisi, rasprave, članci, govori i memorandumi, ur. Vladimir Košćak. Zagreb: Znanje, 1971, 277-290.

RADICA, Bogdan. Agonija Europe. Razgovori i susreti. Zagreb: Disput, 2006.

SAGRAK, Darko. Dr. Milan pl. Šufflay. Hrvatski aristokrat duha. Zagreb: „Darko Sagrak", 1998.

SAID, Edward W. Culture and Imperialism. New York: Vintage Books, 1994.

SAID, Edward W. Orijentalizam. Prev. Biljana Romić. Zagreb: Konzor, 1999.

SCHÖPFLIN, George. „The Functions of Myth and a Taxonomy of Myths”. U: Myths and Nationhood, ur. Geoffrey A. Hosking i George Schöpflin. New York: Routledge, 1997, 19-35.

SELAK, Marija. „Bioetički osvrt na filozofiju Nikolaja A. Berdjajeva. Promišljanje degradacije duhovnosti i bîti tehnike u prijelomu epoha". Filozofska istraživanja 29 (2009), br. 3: 603-614.

SMITH, Anthony D. Nacionalizam i modernizam. Prev. Mirjana Paić Jurinić. Zagreb: Fakultet političkih znanosti, 2003.

SMITH, Anthony D. „The 'Golden Age' and National Renewal”. U: Myths and Nationhood, ur. Geoffrey A. Hosking i George Schöpflin. New York: Routledge, 1997, 36-59.

SMOCOVITIS, Vassiliki Betty. „Evolution”. U: New Dictionary of the History of Ideas, sv. I, ur. Maryanne Cline Horowitz. New York: Charles Scribner's Sons, 2005, 750-758.

STARČEVIĆ, Ante. „Bi-li k Slavstvu ili ka Hrvatstvu?: dva razgovora”. U: Djela dra Ante Starčevića, knj. III: Znanstveno-političke razprave, ur. Josip Bratulić. Varaždin: Inačica, 1995, 3-47.

STERNHELL, Zeev. „National Socialism and Antisemitism: The Case of Maurice Barrès". Journal of Contemporary History 8 (1973), br. 4: 47-66.

STERNHELL, Zeev. The Anti-Enlightenment Tradition. Prev. David Maisel. New Haven; London: Yale University Press, 2010.

SUNIĆ, Tomislav. Europska nova desnica. Korijeni, ideje i mislioci. Zagreb: Hasanbegović, 2009.

ZAITSEV, Oleksandr. „Ukrainian Integral Nationalism in Quest of a 'Special Path' (1920s-1930s)". Russian Politics \& Law 51 (2013), br. 5: 11-32.

ŽANIĆ, Ivo. „Simbolični identitet Hrvatske u trokutu 'raskrižje' - 'predziđe' - 'most”. U: Historijski mitovi na Balkanu, ur. Husnija Kamberović. Sarajevo: Institut za istoriju, 2003, 161-202.

ŽANIĆ, Ivo. „The Curse of King Zvonimir and Political Discourse in Embattled Croatia”. East European Politics and Societies 9 (1995), br. 1: 90-122. 


\section{SUMMARY}

\section{Milan Šufflay's Ideological Views}

The paper attempts to explain Milan Šufflay's ideological views in a broader European context of anti-modernism and counter-Enlightenment tendencies. Milan Šufflay was a critic of the modern world and its manifestations. His views were similar to other counter-Enlightenment thinkers such as Oswald Spengler, Henri Bergson, Gustave Le Bon, etc. Šufflay despised individualism and rationalism, and admired collectivism and power of the myth. Sufflay thought that the answer to problems of the modern world lay in a return to medieval values - i.e. spiritual values against material values, which were predominant in his time.

Šufflay's anti-modernist views were closely connected with his nationalism. He was a proponent of organic nationalism and claimed that a nation is a community of the present, former, and future generations. In his works, he stressed the importance of historical memory, culture, geography, and race as factors in the shaping of the nation. He emphasised the Catholic faith of Croats and Occidentalism, which he claimed manifested through the whole of the nation's history and should therefore be represented in the collective memory of Croats. In that sense, Šufflay's views were similar to those of Croatian interwar nationalists (e.g. Filip Lukas), and he also constructed Croat national identity vis-a-vis Yugoslavism. Because of the great differences between Croats and Serbs, Šuflay claimed that Yugoslavia was an artificial and unsustainable state.

Šufflay's geopolitical insights were also connected with his essentialist vision of the two perennial antagonistic camps - East and West. In that sense, he anticipated Samuel Huntington's idea about the Clash of Civilizations. Sufflay thought that sort of apocalyptic clash between the West, led by an 'Anglo-American bloc', and the East, led by China and India with the Soviet Union as their 'vanguard', was approaching. In that clash, Šufflay argued, the Croats must ally themselves with the West, as they had done throughout their entire history.

Key words: Milan Šufflay; anti-modernism; organic nationalism; Croatian nationalism; geopolitics 